\title{
DECENTRALIZED PATENT SySTEM
}

\section{Lital Helman*}

The patent system features a centralized structure almost from end to end. The United States Patent and Trademark Office (PTO) possesses power to examine inventions, publish patents, and increasingly manage post-examination proceedings. The centralized nature of the patent system leads to well-known inefficiencies, including production problems, low quality patents, and information inefficiencies. Yet, despite intense criticism, and even proposals to 'demonopolize' the agency, the PTO's dominance persists, and has in fact increased with the recent enactment of the America Invents Act (AIA).

This Article considers an alternative, decentralized, patent system. Harnessing new developments in database technology, I propose that inventors would submit patent applications to a shared patent record instead of to the PTO. After a grace period, in which inventions would remain secret, the record would open to the public and the patent examination process would ensue. Following the examination, granted patents would be published to the record. During the examination process and throughout the lifetime of the patent, industry and state actors would be able to dynamically update the record. For example, third parties would be able to submit prior art, scientists - to weigh in on obviousness, patentees-to offer licenses, and courts - to list decisions and outstanding cases that pertain to the patent.

A decentralized patent model fosters a participatory and dynamic patent record and promises to transform the record into a central tool in the innovation economy. This strategy would yield several key benefits. First, it would boost the quality of patent examination and improve productivity, by allowing knowledgeable parties to shoulder some of the tasks that examiners now perform alone. Second, it would spur innovation by advancing information on new inventions and reduce waste by preventing a race for patents that have already been filed. Third, it would allow inventors to avoid innocently infringing patents that are strategically held by 'patent trolls, 'tackling one of the most troubling issues in patent law. Finally, decentralization would facilitate patent licensing, thus driving the adoption of new inventions in the market. Improved licensing forecasts would also produce a dynamic effect: increasing the potential reward of patents ex post, thus boosting the incentive to invent ex ante.

* Professor of Law, Ono Academic College. The author thanks Michael Birnhack, Rochelle Dreyfuss, Niva Elkin-Koren, Sharon Hannes, Gideon Parchomovsky, Ofer Tur-Sinai, Amy Wasserman, and Assaf Yaakov for helpful insights and advice. The author is also grateful for input received in the University of Cambridge Faculty of Law Workshop, the AI: Legal \& Ethical Workshop at Haifa University, the Tel Aviv University workshop for Law and Technology, the Hebrew University Intellectual Property Seminar, and the 2018 Annual Israeli Intellectual Property workshop. 


\section{TABLE OF CONTENTS}

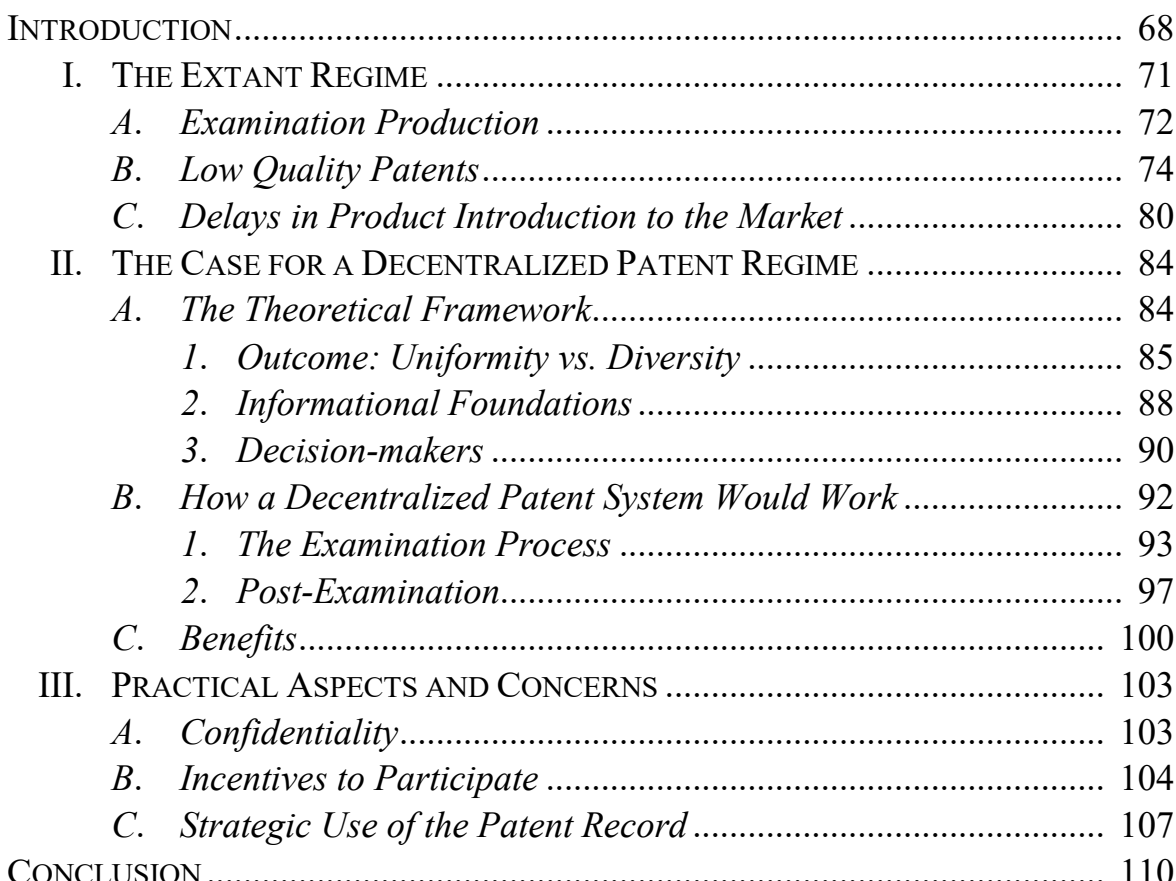

\section{INTRODUCTION}

The structure of the patent system is a fundamental matter. The patent system confers exclusive rights upon inventions after an examination process concludes that the inventions foster a substantial enough leap over the current state of technology. ${ }^{1}$ As a result, patent law is the paradigmatic case for a system in which effectiveness depends not only on the substantive law in place but alsoand perhaps more so- on establishing a structure that supports good decisionmaking on a case-by-case basis. ${ }^{2}$

Currently, the patent system features a centralized structure almost from end to end. The United States Patent and Trademark Office (USPTO or PTO), a federal agency under the Department of Commerce, is in charge of examining inventions to decide which ones merit a patent. ${ }^{3}$ The PTO is also responsible

\footnotetext{
1 See 35 U.S.C. $\S \S 102,103$ (2012 \& Supp. V 2017).

2 See, e.g., Steven Shavell, Foundations of Economic Analysis of Law 152 (2004) (arguing that inventions that do not feature a gap from the technology baseline are likely to occur with or without reward, and do not justify "to suffer the losses associated with patent monopoly.").

3 See 35 U.S.C. $§ 153$ (2012 \& Supp. V 2017); About Us, U.S. Pat. \& Trademark OfF., https://www.uspto.gov/about-us [https://perma.cc/H3K5-S9TQ] (last visited Nov. 29, 2019).
} 
for publishing the granted patents to the public and increasingly for managing post-examination proceedings. ${ }^{4}$

Is a centralized structure optimal for patent decision-making? As I explore below, the answer is almost certainly negative. The centralized nature of the patent system leads to well-known inefficiencies, including production problems, high error rates in the examination outputs, and slow introduction of new technologies to the public. ${ }^{5}$ Indeed, a centralized setting places a single agency in a position of examining the entire pool of patent applications - over which it has no control- thus forcing that agency into a bottleneck and increasing its backlog. Centralization affects the examination error rate because central agencies are more likely to face information problems as well as public choice and other problems that may skew decision-making. ${ }^{6}$ Finally, centralization causes slow introduction of inventions to the public because the PTO lacks critical information and tools that are required for effective communication, distribution, and commercialization of inventions. ${ }^{7}$

Despite all its shortcomings, a central patent office appears inevitable. How else can we ensure adherence to legal standards, consistency, secrecy of underexamination inventions, and an impartial examination process? Indeed, despite intense criticism of the $\mathrm{PTO},{ }^{8}$ and even proposals to "demonopolize" the agen-

4 See Leahy-Smith America Invents Act, Pub. L. No. 112-29, §§ 102(a)(2), 311(a), 125, 321 Stat. 284-86, 299, 305-06 (2011) (codified in scattered sections of 28 U.S.C. \& 35 U.S.C.). A growing body of institutional and empirical research is emerging regarding the PTO's Patent Trial and Appeal Board (PTAB). See, e.g., Brian J. Love \& Shawn Ambwani, Inter Partes Review: An Early Look at the Numbers, 81 U. CHI. L. ReV. Dialogue 93, 94-97 (2014) (offering an initial empirical assessment of PTAB's procedures); Sarah Tran, Patent Powers, 25 HARV. J. L. \& TECH. 609, 613 (2012) (showing that there is a drift to increase the administrative review of patent examination); Saurabh Vishnubhakat, The Youngest Patent Validity Proceeding: Evaluating Post-Grant Review, 24 Tex. InTELl. Prop. L.J. 333, 355 (2016) [hereinafter Vishnubhakat, The Youngest Patent Validity Proceeding] ("The relatively minimal usage of post-grant review in the four years since it became available is starting to change as more patents issue under the first-inventor-to-file provisions . ..."). On the parallel jurisdiction of the PTAB and courts, see, e.g., Mark Consilvio \& Jonathan R.K. Stroud, Unraveling the USPTO's Tangled Web: An Empirical Analysis of the Complex World of Post-Issuance Patent Proceedings, 21 J. InTELl. Prop. L. 33, 41-42 (2013); Paul R. Gugliuzza, (In)Valid Patents, 92 Notre DAME L. ReV. 271, 272-73 (2016) (criticizing the inconsistencies resulting from parallel jurisdiction of the PTO and courts); Saurabh Vishnubhakat et al., Strategic Decision Making in Dual PTAB and District Court Proceedings, 31 BERKELEY. TECH. L.J. 45, 69-70 (2016) (comparing litigants' use of PTAB procedures and Article III litigation).

5 See infra Part I.

6 See John M. Golden, Principles for Patent Remedies, 88 TEx. L. ReV. 505, 516-17 (2010).

7 See infra Part I.

8 See, e.g., James Bessen \& Michael J. Meurer, Patent Failure: How Judges, Bureaucrats, AND LAWYERS Put INNOVATORS AT Risk 141-42 (2008) (arguing that the patent system does not fulfill its mission to boost incentives to innovate); Michael D. Frakes \& Melissa F. Wasserman, Irrational Ignorance at the Patent Office, 72 VAND. L. REV. 975, 977-78 (2019) (arguing that the PTO must improve patent quality); Ron D. Katznelson, Patent Reforms Must Focus on the U.S. Patent Office, MED. InNovations \& Bus., 77, 77-78 (2010) (criticizing the operations of the PTO). 
cy, ${ }^{9}$ the PTO's dominance faces no actual threat and has in fact increased with the recent enactment of the America Invents Act (AIA). ${ }^{10}$

What would an alternative, decentralized patent system look like? One option is to create competition to the PTO's examination services by certifying private examination firms. This option was raised by Michael Abramowicz and John F. Duffy back in 2009. ${ }^{11}$ In this Article, I consider a different idea, which builds on technological advancements in the area of databases and focuses on decentralization of the patent record. Under my proposal, patents would neither be filed to the PTO nor published by the agency. Rather, patents would be filed to a public database that, after a grace period, would be accessible to all. During and following the examination process and throughout the lifetime of the patent, industry and state actors would be able to access the record and add information to it. For example, third parties would be able to submit prior art, scientists would be able to weigh-in on obviousness, patentees would be able to offer licenses, and courts to register decisions and outstanding cases that pertain to the patent. It is also possible to consider a more far-reaching step, to allow industry subject-matter experts to serve as first-line examiners and issue prima facie patent decisions themselves.

Such a system would boost the quality of patent examination and improve examination productivity by providing examiners with more information and allowing knowledgeable scientists to shoulder some of the tasks that PTO examiners now perform alone. It would also generate an accessible and effective patent record that would facilitate the realization of the patents' potential. A comprehensive patent record would generate information advantages and reduce waste by preventing innovators from racing for patents that have already been filed. Such a record would also boost commercialization by facilitating licenses and cooperation on patents.

One natural reaction to this proposal is to argue that it would be impossible under its framework to protect the secrecy of outstanding inventions, avoid conflicts of interest, and ensure good faith of the patent community that participates in creating the patent record. My response to these concerns is set forth below. I propose ways to alleviate these concerns in the form of market incentives, liability rules, and regulatory supervision. I also show that the current re-

\footnotetext{
9 See Michael Abramowicz \& John F. Duffy, Ending the Patenting Monopoly, 157 U. PA. L. REV. 1541, 1543-44 (2009) (proposing to permit private firms to compete with the PTO on patent examination). Other moves that relax the exclusive control of the PTO have occurred or been proposed over the years, including "increased international cooperation and competition in the patent-examining function, experiments in public 'peer' patent review, proposals to require that inventors evaluate their own applications for patents, and calls for establishing a more heterogeneous system of quality gradations in patent examination." Id. at 1543.

10 See Leahy-Smith America Invents Act, Pub. L. No. 112-29, §§ 102(a)(2), 311(a), 125 Stat. 284-86, 299, 305-06 (2011) (codified in scattered sections of 28 U.S.C. \& 35 U.S.C.); see also Saurabh Vishnubhakat, Disguised Patent Policymaking, 76 Wash. \& LeE L. ReV. (forthcoming Fall 2019) (discussing the growth of the PTO's power in the last decade, in particular after the enactment of the AIA).

11 See Abramowicz \& Duffy, supra note 9, at 1543-44.
} 
gime suffers from similar shortcomings and that a decentralized regime would be better equipped to mitigate these issues. I argue further that even as some concerns remain, the benefits of the proposed system strikingly outweigh its costs.

The remainder of this Article is divided as follows. Part I portrays the extant patent regime and the problems it entails. It also shows how these wellknown problems can be traced to the centralized nature of the patent system. Part II sets forth the case for a decentralized patent system. It begins with a theoretical analysis of the costs and benefits of centralized and decentralized systems and outlines three criteria for selection between the two. Part II proceeds in exploring the way that the patent system would operate under the new regime and the expected improvements that are forthcoming with the shift to a decentralized architecture. Part III delves into some of the practical aspects and concerns that need to be worked out before this idea can be put to further consideration. The discussion in Part III includes the questions of secrecy of outstanding inventions, the incentives to participate in the system, and concerns over undesired strategic use of the system. A short conclusion ensues.

\section{The Extant Regime}

The patent system bears crucial importance. The Constitution authorizes Congress " $[t]$ o promote the Progress of Science and useful Arts, by securing for limited Times to Authors and Inventors the exclusive Right to their respective Writings and Discoveries." 12 The patent examination process is the vehicle to identify inventions that justify exclusive rights in order to promote progress. The patent record, in turn, is key to distribute knowledge of patents in order to further knowledge and promote the supply of inventions to the public. ${ }^{13}$

Despite its crucial nature, fundamental concerns pertain to the patent system. First, serious backlogs in the examination process impose delays, costs, and inefficiencies. Second, high error rates persist in patentability decisions,

12 U.S. ConsT. art. I, $\S 8$, cl. 8.

13 See Margo A. Bagley, Patent First, Ask Questions Later: Morality and Biotechnology in Patent Law, 45 WM. \& MARY L. Rev. 469, 546 (2003) (describing patent law as "unashamedly utilitarian"); Peter Lee, Toward a Distributive Agenda for U.S. Patent Law, 55 Hous. L. REV. 321, 323 (2017) (stating same); Mark A. Lemley, Property, Intellectual Property, and Free Riding, 83 Tex. L. Rev. 1031, 1031 (2005) [hereinafter Lemley, Property] (stating that "[i]ntellectual property protection in the United States has always been about generating incentives to create."); Mark A. Lemley, The Surprising Resilience of the Patent System, 95 TEx. L. Rev. 1, 52 (2016) [hereinafter Lemley, The Surprising Resilience] (stating that "[t]he patent system . . . is government regulatory policy: an effort to intervene in the free market in order to encourage more invention than we would otherwise have."); Ted Sichelman, Purging Patent Law of "Private Law" Remedies, 92 Tex. L. REv. 517, 529 (2014) (stating that "[i]n the United States, the overriding goal of patent law is to promote technological innovation."). To be sure, there are deontological accounts of intellectual property and of patent law in particular. See, e.g., Robert P. Merges, Justifying Intellectual Property 3 (2011) (raising the "fundamental rights" theory of patents); see also Bilski v. Kappos, 561 U.S. 593, 617 (2010) (Stevens, J., concurring) ("[t] he patent system is intended to protect and promote advances in science and technology .... ”) (quoting In re Bilski, 545 F.3d 943, 998 (2008)). 
yielding unmerited patents on the market. Finally, the promulgation of new patents to the public is flawed, resulting in delays in product introduction to the market. Below I elaborate on these concerns.

\section{A. Examination Production}

Patent examination is the process that determines whether an alleged invention merits the status of a patent. ${ }^{14}$ The process opens with the inventor filing a patent application with the PTO. ${ }^{15}$ The application is then routed to the relevant art unit - the unit at the PTO that specializes in the scientific field that the application belongs to - and is assigned to an examiner. ${ }^{16}$ The examiner assesses whether the requirements for patentability are present in the invention, including that the invention is novel, nonobvious, and useful, that it comprises subject-matter eligibility, and that the application features adequate disclosure. ${ }^{17}$

Under the extant regime, inventions that seek to assert property rights in the United States must all be validated via a single agency. This situation imposes serious constraints on the system and produces severe costs. Prime among these costs is the prolonged process of patent examination. The PTO reports an average pendency rate of over two years. ${ }^{18}$ The actual pendency rate is probably even higher than reported. ${ }^{19}$ In fact, a 2010 article by Ron Katznelson, the president of BiLevel Technologies, found that 80 percent of granted patents were subject to compensatory patent term adjustments. ${ }^{20}$

1435 U.S.C. $§ 131$ (2012 \& Supp. V 2017) ("The Director shall cause an examination to be made of the application and the alleged new invention; and if on such examination it appears that the applicant is entitled to a patent under the law, the Director shall issue a patent therefor.").

15 Patent Process Overview, U.S. Pat. \& Trademark OfF., https://www.uspto.gov/patentsgetting-started/patent-process-overview\#step1 [https://perma.cc/8YW7-7FK5] (last visited Nov. 27, 2019).

16 See, e.g., Michael D. Frakes \& Melissa F. Wasserman, Is the Time Allocated to Review Patent Applications Inducing Examiners to Grant Invalid Patents? Evidence from Microlevel Application Data, 99 Rev. Econ. \& StAT. 550, 551 (2017).

1735 U.S.C. $\S \S 101-103,112$ (2012 \& Supp. V 2017).

18 See U.S. Pat. \& Trademark Off., The Future of Innovation: Performance \& ACCOUNTABILITY REPORT 15 (2017) [hereinafter USPTO 2017 REPORT], https://www.uspto.gov/sites/default/files/documents/USPTOFY17PAR.pdf [https://perma.cc /Y4HJ-NYJ5].

19 See Data Visualization Center: Pendency, U.S. PAT. \& Trademark OfF., https://www.uspto.gov/corda/dashboards/patents/main.dashxml?CTNAVID=1004 [https://

perma.cc/G68B-QKM5] (last visited Nov. 11, 2019) (explaining that the published pendency rates exclude applications in which RCEs have been filed); see also Mark A. Lemley \& Bhaven Sampat, Examining Patent Examination, 2 Stan. Tech. L. Rev. 1, 1, 9, 18 (2010) (discussing the increase in patent pendency rate); Ron D. Katznelson, My 2010 Wishes for the U.S. Patent Examiner, BI-LEVEL TECHS. 12-13 (2010), http://works.bepress.com/rkatz nelson/60/ [https://perma.cc/M77E-ZTBJ] (criticizing the nontransparent way the USPTO measures pendency rate).

20 See Katznelson, supra note 8, at 77; see also 35 U.S.C. $\$ 154(b)(1)(A)$ (2012 \& Supp. V 2017). 
The infamous backlog at the PTO produces an array of inefficiencies. First, prolonged PTO procedures can increase the costs that inventors incur in the prosecution process. Legal and other expenses compound as the process lingers and becomes more complex. Mounted costs may diminish the incentive to file a patent, and under the assumption that patents form an effective reward for innovation, may negatively affect the incentive to invent. ${ }^{21}$

Prolonged processes also carry distributive effects. ${ }^{22}$ Small firms and individual inventors may be unable to bear the costs of a lingering patent process, and investors may be reluctant to fund these expenses and may delay investments in innovative companies until the company has secured patents. ${ }^{23}$ As a result of funding delays, individual and small firm inventors may be unable to pursue their ventures, or may decide to give up on patent protection, thus exposing their inventions to copying and conceding to an inferior position in the marketplace. ${ }^{24}$

While the costs of patent prosecution increase, delays reduce the patentee's benefits from acquiring a patent. The patent monopoly is limited in time, and the clock begins ticking at the application filing date. ${ }^{25}$ The benefits patents entail, however, fully commence only when the patent is granted at the end of the examination process. ${ }^{26}$ As a result, pendency at the PTO shrinks the duration and thus the value of patent protection. ${ }^{27}$

High pendency rates at the PTO generate snowball effects. Delays keep the PTO occupied with the effects of the delays, thus exacerbating and selfperpetuating the problem. Indeed, the PTO must divert resources to corresponding with patentees, managing legal challenges, and engaging in other distrac-

${ }^{21}$ Doubts that patents actually promote innovation abound. See, e.g., BESSEN \& MEURER, supra note 8, at 14, 16 (arguing that patents promote innovation only in some industries); Mark A. Lemley, Faith-Based Intellectual Property, 62 UCLA L. REV. 1328, 1334 (2015) [hereinafter Lemley, Faith-Based Intellectual Property] (stating same); Lemley, The Surprising Resilience, supra note 13, at 52 (arguing that "persuasive evidence that the patent system drives innovation is surprisingly hard to come by"); Petra Moser, How Do Patent Laws Influence Innovation? Evidence from Nineteenth-Century World's Fairs, 95 AM. ECON. REV. 1214, 1221 (2005) (finding that patents promote innovation when copying or reverse engineering are easy in a particular industry).

22 See Lee, supra note 13, at 323 (discussing distributive considerations in patent law).

23 See Lemley, The Surprising Resilience, supra note 13, at 53 (noting that patents facilitate venture financing).

24 Arti Rai et al., U.S. Dep'T of Commerce, Patent Reform: Unleashing InNovation, Promoting Economic Growth \& Producing High-Paying Jobs 1 (2010), http://www.heartland.org/_template-assets/documents/publications/27635.pdf [https://perm a.cc/G5EG-X34D] (citing reports that "the U.S. backlog [] could ultimately cost the U.S. economy billions of dollars annually in 'foregone innovation." ").

2535 U.S.C. $\$ 154(a)(2)$ (providing that patents shall last for a "term beginning on the date on which the patent issues and ending 20 years from the date on which the application for the patent was filed in the United States ....").

${ }_{26} \mathrm{Id}$.

27 Of course, some benefits already occur when the patent is filed, such as strategic use of the "patent pending" status. Cf. Lemley, The Surprising Resilience, supra note 13, at 53-54 (arguing that patentees may apply for patents for reason unconnected to their validity). 
tions that require resources that the PTO and the patent community could have used for other, productive tasks. ${ }^{28}$

Some of the delays in the examination process could probably be improved with better management and process improvements. ${ }^{29}$ Indeed, the PTO has shown improvement over the years, and its goals for the coming year include another step forward. ${ }^{30}$ Yet, the core problem lies not with any individual policy of the PTO but with the very central structure of the process. First and foremost, the fact that the large volume of patent applications must be examined by one single agency is bound to congest the system. Consider also that the volume of patent applications is beyond the control of the agency, ${ }^{31}$ and that although it may be possible to largely estimate the annual growth in total applications, it is unrealistic to expect the PTO to predict the areas of science that future applications would fall under and their complexity levels. ${ }^{32}$ Worse yet, as a governmental agency, even if the workload were somehow predictable, the PTO would still be unable to dynamically adapt its workforce to the varying tasks and the required skillsets. ${ }^{33}$ This inherent unpredictability and inflexibility renders it anything but impossible to manage the workload of patent examination effectively via central planning.

\section{B. Low Quality Patents}

A second key problem with the extant regime concerns the quality of patents. This issue has troubled the patent community for many years. ${ }^{34}$ Scholars

${ }^{28}$ Katznelson, supra note 8, at 77 ("Irregularities in examination procedure and administrative rulemaking have plagued the Office, resulting in successful legal challenges against the Office and causing costly distractions for the Office and the patent community.").

${ }^{29}$ Indeed, some PTO policies and practices exacerbate its backlog. One such practice concerns the ability of applicants to infinitely argue against patent rejection. Even after "final rejection," applicants can reamend claims, request an in-person interview with the examiner, file a continuation, or appeal. See Michael D. Frakes \& Melissa F. Wasserman, Empirical Scholarship on the Prosecution Process at the USPTO, in 1 RESEARCH HANDBOOK ON THE ECONOMics of Intellectual Property Law 77, 81 (Ben Depoorter \& Peter S. Menell eds., 2019) (Upon receiving a final rejection, "an aggrieved patent applicant can always choose to start the examination process over by filing a continuation application," appealing the denied application to the Patent Trial and Appeal Board, or abandoning the application altogether). Other examples abound. See, e.g., Wen Xue, Note, Obviousness Guidance at the PTO, 5 N.Y.U. J. InTELl. Prop. \& ENT. L. 306, 321 (noting that internal systems in the PTO encourage junior examiners to issue many office actions, which prolongs the process); Katznelson, supra note 8, at 85-86 (proposing ways to increase efficiency at the PTO).

30 See, e.g., USPTO 2017 REPORT, supra note 18, at 15.

31 But see infra notes 61-62 and accompanying text.

32 See Katznelson, supra note 19, at 13 (noting that the PTO's estimates have often missed the mark).

33 See id. at 12 (discussing "[t]he profound inability of the USPTO to project application loads ...."); see also Abramowicz \& Duffy, supra note 9, at 1548 ("[T] he process that determines whether and when the PTO can grow is largely a political one, rather than a business decision by the PTO itself.").

34 See, e.g., Bessen \& Meurer, supra note 8, at 3; AdAm B. JAFFe \& Josh Lerner, InNovation and its Discontents: How Our Broken Patent System is Endangering 
have decried both type-one errors, namely, denying patents of merited inventions (false negatives) and type-two errors, namely, allowing patents to nondeserving inventions (false positives). ${ }^{35}$ Between the two, the concern over false positives has been most prominent for a number of reasons. ${ }^{36}$ One reason is that there are probably more false positives than false negatives, if only because the number of trivial technological advances outnumbers revolutionary ones. ${ }^{37} \mathrm{~A}$ second reason is that false positives are more likely to remain uncorrected because there are greater incentives for patentees to dispute false negatives than there are for third parties to contest false positives. ${ }^{38}$ Third parties face collective action and other problems that discourage them from pursuing a cost-intensive process that would benefit their competitors, among others. ${ }^{39}$ As

Innovation and Progress, and What to Do About it 2, 10-13 (2004); Fed. Trade Commission, To Promote innovation: The Proper Balance of Competition and PATENT LAW AND POLICY 5-7 (2003), https:/www.ftc.gov/sites/default/files/documents/ reports/promote-innovation-proper-balance-competition-and-patent-law-and policy/innov ationrpt.pdf [https://perma.cc/R2YK-UQVB]; Nancy T. Gallini, The Economics of Patents: Lessons from Recent U.S. Patent Reform, 16 J. ECON. PERSP. 131, 147 (2002) (discussing costs of granting questionable patents); Shubha Ghosh \& Jay Kesan, What Do Patents Purchase? In Search of Optimal Ignorance in the Patent Office, 40 Hous. L. REV. 1219, 1228 (2004) (discussing the social costs of low-quality patents).

35 See Ronald E. Walpole \& Raymond H. Myers, Probability and Statistics for ENGINEERS AND SCIENTISTS 290 (4th ed. 1989) ("Rejection of the null hypothesis when it is true is called a type I error ... . Acceptance of the null hypothesis when it is false is called a type II error." (emphasis omitted)).

36 See Frakes \& Wasserman, supra note 29, at 77 ("There is widespread agreement that the [PTO] allows too many invalid patents to issue that unnecessarily drain consumer welfare ... .”); Roger Allan Ford, The Patent Spiral, 164 U. PA. L. REv. 827, 831-32 (2016) (discussing weak patents); John F. Luman III \& Christopher L. Dodson, No Longer a Myth, the Emergence of the Patent Troll: Stifling Innovation, Increasing Litigation, and Extorting Billions, 18 InTELl. Prop. \& TECH. L.J. 12, 13 (2006) (discussing the prevalence and costs of weak patents); see also sources cited supra note 34.

37 See Michael D. Frakes \& Melissa F. Wasserman, Does the U.S. Patent and Trademark Office Grant Too Many Bad Patents?: Evidence from a Quasi-Experiment, 67 STAN. L. REV. 613, 622-23 (2015) (citing empirical findings that the PTO grants invalid patents); see also Xue, supra note 29, at 317 ("Because the number of trivial advances in technology outbalances revolutionary ones, the obviousness doctrine may give rise to more instances of false positives than false negatives.").

38 See Joseph Farrell \& Robert P. Merges, Incentives to Challenge and Defend Patents: Why Litigation Won't Reliably Fix Patent Office Errors and Why Administrative Patent Review Might Help, 19 BerKeley TECH. L.J. 943, 951 (2004); Vishnubhakat, The Youngest Patent Validity Proceeding, supra note 4, at 337 ("Of the two aforementioned types of patent examination errors that the USPTO may commit-improper grants and improper denials - the latter are generally of less concern because administrative and judicial review are available for applicants to challenge such denials.").

39 See Blonder-Tongue Labs., Inc. v. Univ. of Ill. Found., 402 U.S. 313, 334 (1971) (holding that defeated patentees are estopped from litigating the patent's validity in future cases); see also Roger Allen Ford, Patent Invalidity Versus Noninfringement, 99 CORNELL L. REV. 71, 110-14 (2013) (analyzing the disincentive of patent defendants to bear the cost of defeating a patent); Lemley, The Surprising Resilience, supra note 13, at 44 ("Invalidating the patent benefits their competitors, who can free ride on the service the challenger provided."); Joseph Scott Miller, Building a Better Bounty: Litigation-Stage Rewards for Defeating Patents, 19 BERKELEY TECH. L.J. 667, 687-88 (2004) (analyzing the disincentive of patent defend- 
Saurabh Vishnubhakat explains, "patent invalidity judgments are public goods that are susceptible to familiar problems of free riding and undersupply." ${ }^{40} \mathrm{~A}$ third reason concerns internal incentives and biases at the PTO, which lead examiners to grant patents in borderline cases, such as budgetary concerns over costly disputes with denied patent applicants. ${ }^{41}$

Granting invalid patents while denying valid ones obviously undermines the system. ${ }^{42}$ False negatives deny inventors of the protection that would allow them to recoup their investment in research and development (R\&D). Ex ante, uncertainty regarding the outcome of patent prosecution may discourage patent prosecution and perhaps even R\&D more generally. ${ }^{43}$

Ubiquitous false positives, on the other hand, generate an abundance of weak inventions with strong monopoly rights. This effect may stifle innovation, by inhibiting competition with patented technologies. ${ }^{44}$ Indeed, Alberto Galasso and Mark Schankerman find that innovation by small firms has been triggered by invalidations of large firms' patents, suggesting that those patents were thwarting these innovative efforts. ${ }^{45}$ False positives may also create undue monopoly costs, such as excessive deadweight loss, inflated pricing, and competitive harms. ${ }^{46}$ False positives produce waste as well, as the patent community diverts resources to acquire, enforce, maintain, and litigate patents that should not have been granted in the first place. ${ }^{47}$ Relatedly, unmerited patents can con-

ants to bear the cost of defeating a patent); John R. Thomas, Collusion and Collective Action in the Patent System: A Proposal for Patent Bounties, 2001 U. ILl. L. Rev. 305, 333 (2001).

40 Vishnubhakat, The Youngest Patent Validity Proceeding, supra note 4, at 341.

41 See, e.g., Frakes \& Wasserman, supra note 37, at 619 (summarizing the reasons offered in the scholarship for the PTO's tendency to grant borderline patents); Xue, supra note 29, at 322 (citing reason for the fact that " $\mathrm{t}]$ he PTO prosecution practice is set up in a way so that borderline patents are more likely to be granted rather than rejected ....”).

42 But see Mark A. Lemley, Rational Ignorance at the Patent Office, 95 Nw. U. L. REv. 1495, 1502 (2001) [hereinafter Lemley, Rational Ignorance] (arguing that it may be cost effective not to invest in improving patent examination at the PTO level). For a rebuttal to Lemley's argument based on new empirical evidence, see Frakes \& Wasserman, supra note 37 , at $622-23$.

43 See Andres Sawicki, Better Mistakes in Patent Law, 39 Fla. ST. U. L. Rev. 735, 760-61 (2012) (arguing that excessive patent denials represent a dynamic social cost in the form of lost incentives to invest in future research).

44 See, e.g., Fed. TRade Comm'N, supra note 34, at 5-7 (arguing that questionable patents stifle innovation and generates other costs); see also Sawicki, supra note 43, at 742.

45 See Alberto Galasso \& Mark Schankerman, Patents and Cumulative Innovation: Causal Evidence from the Courts, 130 Q.J. ECON. 317, 322 (2015).

46 See, e.g., T. Randolph Beard et al., Quantifying the Cost of Substandard Patents: Some Preliminary Evidence, 12 YALE J.L. \& TECH. 240, 242 (2010) (estimating the losses resulting from false positives in up to $\$ 21$ billion annually, including deterring research, deadweight loss, litigation and administrative costs); Frakes \& Wasserman, supra note 37, at 625-28 (discussing costs of weak patents).

47 See, e.g., Beard et al., supra note 46, at 242; see also JAFFE \& LERNER, supra note 34, at 30 (arguing that the patent system creates a net social loss by increasing litigation and litigation threat); Ghosh \& Kesan, supra note 34, at 1239, 1252 (finding that the low obviousness standard in gene sequence patents generates costs); Jay P. Kesan \& Andres A. Gallo, Why "Bad" Patents Survive in the Market and How Should We Change?-The Private and Social 
tribute to the 'patent troll' phenomenon by allowing nonpracticing entities (NPEs) to accumulate vast portfolios of dubious patents and use them for strike suits. $^{48}$

Rife errors are not likely to be simply the fault of individual patent examiners. Rather, they reflect more fundamental flaws in the system. I suggest that the flaws largely stem from the central nature of the patent system. Indeed, as I argue in Part II, a central agency is prone to errors in conducting highly contextual, fact-intensive, and industry-specific inquiries, such as the ones that patent examinations entail, because they have limited access to the relevant information for such inquiries. ${ }^{49}$

What is more, as Part II elaborates, central agencies typically operate via fulltime employees. In the realm of patent examination, this pattern invites errors. First, fulltime examiners are indeed examiners full time, and do not practice science anymore. They may therefore lack up-to-date knowledge of the current state of technology to make good patentability decisions..$^{50}$ In fact, PTO examiners obtain technical knowledge primarily via repeated examinations. ${ }^{51}$ This method is suboptimal, especially in industries that feature low incentives to publish and in emerging tech domains, where patents are yet to be filed and

Costs of Patents, 55 Emory L.J. 61, 77 (2006); Ronald J. Mann, Do Patents Facilitate Financing in the Software Industry?, 83 TEX. L. REV. 961, 1026 (2005) (arguing that many software patents cover obvious inventions).

48 See Ford, supra note 39, at 113 (noting that weak patents can form the basis for strike suits); Doug Lichtman \& Mark A. Lemley, Rethinking Patent Law's Presumption of Validity, 60 StAN. L. REV. 45, 48 (2007) ("Sadly, a large and growing number of 'patent trolls' today play this exact strategy, using patents on obvious inventions quite literally to tax legitimate business activity."). NPEs are main players in patent litigation. See, e.g., JAFFE \& LERnER, supra note 34, at 47-49; James Bessen, The Evidence is in: Patent Trolls Do Hurt Innovation, HARV. Bus. REV. (Nov. 2014), https://hbr.org/2014/07/the-evidence-is-in-patenttrolls-do-hurt-innovation [https://perma.cc/KAG2-6AEP] (stating that NPEs file the majority of patent suits); 2015 Patent Dispute Report, Unified PATENTS fig.7 (Dec. 31, 2015), https://www.unifiedpatents.com/news/2016/5/30/2015-patent-dispute-report [https://perma .cc/6629-WE2R] (showing that NPEs filed $66.9 \%$ of district court suits in 2015). But see Andrei Iancu, Dir., U.S. Patent \& Trademark Office, Remarks Delivered at the Eastern District of Texas Bar Association Inaugural Texas Dinner (Oct. 18, 2018) (dismissing concerns of patent trolls); Richard Lloyd \& Joff Wild, New US Litigation Stats Analysis Suggests Much Greater Role for Lone Inventors, IAM (Oct. 12, 2018), https://www.iammedia.com/defensive-aggregation/breaking-down-latest-us-patent-litigation-stats [https://per ma.cc/58XS-WMVK] (showing that the share of 'trolls' in litigation has fallen in recent years).

49 See infra Section II.A.

50 See Rebecca S. Eisenberg, Obvious to Whom? Evaluating Inventions from the Perspective of PHOSITA, 19 BERKELEY TECH. L.J., 885, 898 (2004) (“[Examiners'] technological training and skills can only atrophy and get out of date as their skills as patent examiners grow."). 51 The PTO attempts to place examiners in art units where they have former experience. Even when such a placement is infeasible, examiners typically spend their entire career at the Office examining one type of technology, acquiring expertise in the process. See id. (arguing same). 
examined. ${ }^{52}$ As a result, patents that should be invalidated on prior art grounds may nevertheless pass this hurdle.

Second, examiners may lack the technological expertise to make good $o b$ viousness decisions. Patent law requires examiners to examine obviousness from the perspective of "a person having ordinary skill in the art," a standard known as PHOSITA, in acronym. ${ }^{53}$ But despite their technical backgrounds, PTO examiners do not themselves embody the standard of PHOSITA, and courts have made this point clear by consistently rejecting PTO decisions that were based on examiners' own technological skills or common sense. ${ }^{54}$ To determine obviousness, PTO examiners are therefore expected to inhabit the perspective of a hypothetical technical expert and retroactively estimate what that technical expert would have thought about an invention at a past time. ${ }^{55}$ Such decisions are very hard to make, and the more delayed the process grows, the more indeterminable they become. ${ }^{56}$ Knowledge deficiency may in particular lead to type-two errors, because obvious inventions may appear nonobvious to the examiner. ${ }^{57}$

52 Richard Levin, President, Yale Univ., Hearing Before the FTC: Competition and Intellectual Property Law and Policy in the Knowledge-Based Economy 101 (Feb. 6, 2002), https://www.ftc.gov/sites/default/files/documents/public_events/competition-ip-law-policyknowledge-based-economy-hearings/020206ftc.pdf [https://perma.cc/F72L-RYFS] (“Almost by definition new areas of technology lack well-developed bodies of prior art in earlier patents and in the published literature. This makes it difficult for patent examiners to determine whether a claim meets the required test of . . obviousness."); Melissa F. Wasserman, The PTO's Asymmetric Incentives: Pressure to Expand Substantive Patent Law, 72 Оніо ST. L.J. 379, 415 (2011) ("[T]he Agency lacks either a staff with significant knowledge in this technology or the resources necessary to review patent applications in [an] emerging field."); Xue, supra note 29, at 318 (discussing same).

5335 U.S.C. $\$ 103$ (2012 \& Supp. V 2017).

${ }^{54}$ See, e.g., In re Sang-Su Lee, 277 F.3d 1338, 1345 (Fed. Cir. 2002) (“'Common knowledge and common sense,' even if assumed to derive from the agency's expertise, do not substitute for authority when the law requires authority.") (citation omitted); In re Zurko, 258 F.3d 1379, 1386 (Fed. Cir. 2001) (“"T] he Board cannot simply reach conclusions based on its own understanding or experience - or on its assessment of what would be basic knowledge or common sense."); In re Rouffet, 149 F.3d 1350, 1358 (Fed. Cir 1998) (rejecting Board's conclusion that failed to "explain the specific understanding or principle"). This is not to say that examiners' "gut feeling" does not in fact matter. Empirical evidence shows that although "the examiner is not allowed to use his 'gut feeling' to determine an application's patentability," examiners exert greater effort to invalidate applications that they feel are weak. See Zhen Lei \& Brian D. Wright, Why Weak Patents? Rational Ignorance or Pro“customer” Tilt? 9 (Agric. \& Applied Econ. Ass'n, Working Paper No. 49279, 2009).

55 See In re Kotzab, 217 F.3d 1365, 1369 (Fed. Cir. 2000) ("A critical step in analyzing the patentability of claims pursuant to section 103(a) is casting the mind back to the time of invention, to consider the thinking of one of ordinary skill in the art, guided only by the prior art references and the then-accepted wisdom in the field."); In re Dembiczak, 175 F.3d 994 , 999 (Fed. Cir. 1999) ("Measuring a claimed invention against the standard established by section 103 requires the oft-difficult but critical step of casting the mind back to the time of invention .....”).

56 See Eisenberg, supra note 50, at 887 (discussing the two main administrative challenges in applying the PHOSITA standard: "the problem of timing and the problem of skill level").

57 See id. at 887 ("An invention that seems obvious to a person having ordinary skill in the field might nonetheless seem patentworthy to a person who lacks such skill, even after read- 
The problem of patent quality is further aggravated by the PTO's high pendency rate. The first reason for that is because time constraints and workload at the PTO allows inadequate time for examiners to review applications, let alone to develop professionally and keep up to date with technical knowledge..$^{58}$ Time deficiency results in unmerited patents, because the less time an examiner has to look for reasons to invalidate a patent, the less likely she is to find any. ${ }^{59}$ The second way that high pendency rates affect quality is by increasing the likelihood of errors and biases. For example, examiners who need to evaluate obviousness of an invention long after the invention has been conceived are more prone to hindsight bias, namely, to finding the invention obvious even if it was not obvious at the time the patent was filed. ${ }^{60}$ Third, and finally, pressures on the PTO to improve its productivity affect the incentives at the agency. At some point in time, the PTO allegedly adopted a policy to deny patents in order to

ing the prior art record."); Gregory Mandel, The Non-Obvious Problem: How the Indeterminate Nonobviousness Standard Produces Excessive Patent Grants, 42 U.C. DAVIS L. REV. 57, 99 (2008).

58 See Frakes \& Wasserman, supra note 16, at 552 ("On average, a[n]. . examiner spends only nineteen hours reviewing an application [including][] reading the patent application, searching for prior art, comparing the prior art with the [patent] application, writing a rejection, responding to the patent applicant's arguments, and often conducting an interview with the applicant's attorney."); Gene Quinn, High Value Patents-Where Strength Meets Quality, IPWATCHDOG (Dec. 11, 2014), http://www.ipwatchdog.com/2014/12/11/high-value-pa tents-where-strengthmeets-quality/id=52569/ [https:/perma.cc/UZ5J-MPDB] (quoting Stephen Kunin, former Deputy Commissioner for Patent Examination Policy) ("It is unrealistic to expect an examiner to thoroughly review an average of nearly 50 references per patent in the 16 to 17 hours an examiner can spend per patent while processing the necessary number of patent applications.").

59 Frakes \& Wasserman, supra note 16, at 560; see also id. at 552 (discussing the "presumption of validity," which dictates that in the absence of an invalidating reason, the examiner is bound to grant the patent).

60 See Eisenberg, supra note 50, at 887 ("An invention that was in fact nonobvious at the time it was made might nonetheless appear obvious by the time it is evaluated for patentability some years later, especially to those who have read the inventor's disclosure."); Xue, supra note 29, at 314. For empirical demonstration of hindsight bias see, e.g., Gregory N. Mandel, Another Missed Opportunity: The Supreme Court's Failure to Define Nonobviousness or Combat Hindsight Bias in KSR v. Teleflex, 12 LEWIS \& CLARK L. REV. 323, 337-38 (2008); Gregory N. Mandel, Patently Non-Obvious II: Experimental Study on the Hindsight Issue Before the Supreme Court in KSR v. Teleflex, 9 YALE J.L. \& TECH. 1, 18-20 (2007); Gregory N. Mandel, Patently Non-Obvious: Empirical Demonstration That the Hindsight Bias Renders Patent Decisions Irrational, 67 OHIO ST. L.J. 1391, 1411-14 (2006); cf. In re Kotzab, 217 F.3d at 1369 ("A critical step in analyzing the patentability of claims pursuant to section 103(a) is casting the mind back to the time of invention, to consider the thinking of one of ordinary skill in the art, guided only by the prior art references and the then-accepted wisdom in the field."); In re Dembiczak, 175 F.3d at 999 ("Measuring a claimed invention against the standard established by section 103 requires the oft-difficult but critical step of casting the mind back to the time of invention."); Jeffrey J. Rachlinski, A Positive Psychological Theory of Judging in Hindsight, 65 U. CHI. L. REv. 571, 571-72 (1998) (defining, based on cognitive psychology literature, "hindsight bias" as the tendency of people to exaggerate at hindsight what could have been anticipated in foresight). 
discourage filings of new applications. ${ }^{61}$ To the contrary, the PTO may now be incentivized to grant rather than deny borderline patents, because granting a patent usually ends the process (and leads to fees being paid to the PTO), while denied applicants can file continuations. ${ }^{62}$

\section{Delays in Product Introduction to the Market}

Following the examination process or after eighteen months, whichever comes earlier, the PTO publishes the granted patents in a public record. ${ }^{63}$ The patent record serves two imperative purposes. The first purpose is to provide knowledge to the scientific community regarding patented inventions. ${ }^{64}$ This is a critical mission. Patent law is frequently described as offering a rights-fordisclosure bargain, in which society provides limited-term rights to the inventor in exchange for public disclosure of her invention and means of its creation and use. ${ }^{65}$ Disclosure of patents can direct future innovators to perform permissible activities that would further research and development. ${ }^{66}$ Knowledge of patents may also prevent waste and duplicate efforts of inventors who have raced for the same invention and can free their resources to pursue other ventures.

61 See Wasserman, supra note 52, at 415 ("[T] stance on patentability standards will result in the filing of fewer patent applications.”).

62 See Frakes \& Wasserman, supra note 37, at 616; see also Xue, supra note 29, at 321.

63 See 35 U.S.C. $\S 122(b)(1)$ (2012 \& Supp. V 2017); 37 C.F.R. § 1.211 (2018).

64 See Wendy J. Gordon, Intellectual Property, in The Oxford Handbook of Legal Studies 617, 632 (Peter Cane \& Mark Tushnet eds., 2003); Rebecca S. Eisenberg, Patents and the Progress of Science: Exclusive Rights and Experimental Use, 56 U. CHI. L. REV. 1017, 1028-29 (1989) (explaining how patents create "incentive[s] to disclose").

65 See Joseph Barnes, Treatise on the Justice, Policy, and Utility of Establishing an Effectual System for Promoting the Progress of Useful Arts 25 (Philadelphia, Francis Bailey, 1792) (describing "a mutual contract between the inventor and the public, in which the inventor agrees, on proviso that the public will secure to him his property in, and the exclusive use of his discovery for a limited time, he will, at the expiration of such time, cede his right in the same to the public: thenceforth the discovery is common right, being the compensation required by the public, stipulated in the contract, for having thus secured the same."); Jeanne C. Fromer, Patent Disclosure, 94 IowA L. REV. 539, 553 (2009) ("The accepted understanding in patent policy and doctrine is that disclosure of a patented invention to the public - and its dedication to the public after the expiration of the patent term-is part of a quid pro quo the patentee must provide to gain the broad patent right."); John M. Golden, "Patent Trolls" and Patent Remedies, 85 Texas L. Rev. 2111, 2117 (2007) ("In general, patents are believed to serve their constitutional purpose . . . by providing for an exchange: in exchange for public disclosure . ..., the public provides a limited-term 'right to exclude' ....”); see also Universal Oil Prods. Co. v. Globe Oil \& Ref. Co., 322 U.S. 471, 484 (1944) ("[T] he quid pro quo is disclosure of a process or device in sufficient detail to enable [a person] skilled in the art to practice the invention once the period of the monopoly has expired.").

66 This argument corresponds to the literature regarding user innovations, which emphasize the benefits to innovation from enabling users to engage with patented products. See, e.g., ERIC VON HiPPEl, Democratizing InNOVATION 1 (2005); William W. Fisher III, The Implications for Law of User Innovation, 94 MinN. L. REV. 1417, 1455-57 (2010); Katherine J. Strandburg, Users as Innovators: Implications for Patent Doctrine, 79 U. Colo. L. REV. 467, 468-69 (2008); Andrew W. Torrance \& Eric von Hippel, The Right to Innovate, $2015 \mathrm{MicH}$. ST. L. REV. 793, 823-24. 
The second purpose of the patent record is to accelerate the speed with which inventions are introduced to the market. ${ }^{67}$ This goal is achieved by removing information barriers and communicating well-defined property rights to market players who can then transact with patentees. ${ }^{68}$ In that sense, information serves to reduce transaction costs and to promote licensing of patents, which can boost the supply of technology-based products and increase the potential reward for the innovator. ${ }^{69}$

Under the extant regime, the patent record hardly fulfills any of these functions satisfactorily. First, the record is complicated to understand and is accessible to neither scientists nor potential licensees, unless they possess established knowledge of the patent system or access to costly patent search professionals. ${ }^{70}$ As discussed above, high costs also involve distributive effects because they disproportionately affect players who lack the resources to invest in patent searches. ${ }^{71}$ This effect is palpable in our context, rendering it likely that entrenched firms would be able to learn about patents and new players in their field more than less-affluent start-up ventures. ${ }^{72}$

Another key problem with the current record is that it is insufficiently comprehensive. Beyond technical filing information, the extant patent record

67 See Gaia Bernstein, In the Shadow of Innovation, 31 CARdozo L. REv. 2257, 2259 (2010) ("Attaining the progress objective ... requires not just innovation but also an adoption process. Progress can be attained only if people adopt and use the new technology."); see also Kewanee Oil Co. v. Bicron Corp., 416 U.S. 470, 480 (1974) (holding that patent law's "positive effect on society [is achieved] through the introduction of new products and processes of manufacture into the economy, and the emanations by way of increased employment and better lives for our citizens").

68 See Golden, supra note 6, at 520-21 (discussing how patents stimulate disclosure and innovation); see also Dan L. Burk, Intellectual Property and the Firm, 71 U. CHI. L. REV. 3, 9 (2004) (arguing that property rights in patents can promote coordination and transactions).

69 See F. Scott Kieff, Property Rights and Property Rules for Commercializing Inventions, 85 MinN. L. REV. 697, 710 (2001) (suggesting that the patent system must provide "incentives to commercialize" the invention).

70 Gene Quinn, Patent Search 101: Why US Patent Searches are Critically Important, IPWATCHDOG (Jan. 13, 2018), https://www.ipwatchdog.com/2018/01/13/patent-search-101patent-searches/id=92305/ [https://perma.cc/RJ2M-9W4U] ("[B]efore spending thousands of dollars to obtain a patent you should obtain a professional patent search and patentability opinion."); Gene Quinn, Patent Searches are Always a Good Idea, Even if Your Invention is Not on the Market, IPWATCHDOG (Feb. 27, 2016), https://www.ipwatchdog.com/2016/02/27/ patent-searches-always-good-idea/id=66601/ [https://perma.cc/P3DK-EVJM] (noting that "patent searching is an art that requires enormous practice."); see also SHOBITA Parthasarathy, Patent Politics: Life Forms, Markets, and the Public Interest in THE United STATES AND EuROPE 27-28 (2017) (discussing the vast influence of patent professionals, including patent lawyers, alongside large corporate patent-filers and patent office personnel, on the design of the patent system).

71 See supra note 22 and accompanying text.

72 As a result of the record complexity, private firms have created patent search tools. While these tools are free and easy to use, they are limited, and may also be informing the firms that operate them (such as Google) what inventors are searching for, which may deepen distributive concerns. See, e.g., FreE PATENTS OnLine, http://www.freepatentsonline.com/ [https://perma.cc/7A5G-SP3G] (last visited Oct. 14, 2019); GOOGLE PATENT SEARCH, https:// www.google.com/?tbm=pts [https://perma.cc/B2QT-GW4Q] (last visited Oct. 14, 2019). 
only includes a description of the invention, the patent claims, and exclusive licenses that apply to the invention..$^{73}$ The record includes little or no information that precedes the date of filing the application, such as prior art, lab notes, information that would enable repairs if needed, and other information about the invention..$^{74}$ It also lacks information about court cases that concern the patent or that are pending against it. Worse yet, the record holds no information about available licenses - let alone the ability to act on such licenses or use them.

The inadequacy of the patent record is highly disturbing. It may be a key reason that under today's regime, the lion's share of patents is never commercialized, licensed, or used. ${ }^{75}$ The suboptimal level of the patent record also contributes to the "patent-troll problem," by leading to innocent uses of patents by technology firms. These firms are then threatened with strike suits by NPEs who purchased these patents from their original owners for precisely this purpose. $^{76}$

Record deficiencies largely stem from the centralized architecture of the system. The PTO does not own the information that is needed in order to maintain an effective patent database, such as transactional or litigatory information. Such information is located in the hands of patentees and of other industry and state players. ${ }^{77}$ What is more, much of this information is dynamic and is changing overtime. A central agency cannot realistically be responsible to collect and register updates to the record, including changes to the transactional or litigatory status of millions of patents in real time.

Delays in patent examination also contribute to the inadequate nature of the patent record. The first reason for that is obvious. Delayed examination translates to delayed publication and to wasted efforts by competitors who have been operating in the space of the patent and must refrain from exploiting the

73 See U.S.C. § 112(a) (2012 \& Supp. V 2017) (providing that the patentee needs to disclose "the manner and process of making and using" the invention); see also 313 Recording of Licenses, Security Interests, and Documents Other than Assignments [R-07.2015], U.S. PAT. \& TRADEMARK OFF., https://www.uspto.gov/web/offices/pac/mpep/s313.html [https://perma.cc /N2UD-YLDQ] (last visited: Oct. 5, 2019); Search for Patents, U.S. PAT. \& TRADEMARK OFF., https://www.uspto.gov/patents-application-process/search-patents [https://perma.cc /99AU-59TA] (last visited Nov. 13, 2019).

74 Id. (detailing the items that the record entails).

75 See Lemley, Faith-Based Intellectual Property, supra note 21, at 1334; Lemley, Rational Ignorance, supra note 42 , at 1511 . It is possible to argue that patentees' lack of motivation to sell drives the lack of commercialization. Yet, it is also clear that at its current state, the record does not serve an effective vehicle to commercialize inventions or to channel innovation to the market.

76 See sources cited supra note 48.

77 See, e.g., Alan C. Marco et al., Patent Litigation Data from US District Court Electronic Records 4-5 (U.S. Pat. \& Trademark Off., Economic Working Paper No. 2017-06, 2017), https://ssrn.com/abstract=2942295 (discussing the lack of patent litigation databases and the efforts to create a patent litigation data pilot). 
invention once the patent is published. ${ }^{78}$ Second, and more crucially, instead of accelerating the time an invention is disclosed to the public, delays create an incentive for inventors to shun from disclosing their invention, commercializing it, or otherwise offering the invention to the public, until the processes at the PTO are completed because of the uncertainty regarding the patentability scope they would be awarded. ${ }^{79}$

The inefficiencies in the patent system did not go unnoticed by either Congress, the judiciary, or the PTO ${ }^{80}$ The AIA set out to grant the PTO, inter alia, responsibility over fee setting, generated new proceedings to weed out weak patents, and granted the PTO substantive authorities. ${ }^{81}$ The Supreme Court, with a renewed interest in patent law, has, among other things, tightened the nonobviousness doctrine, providing grounds for the PTO to deny unmerited patent applications. ${ }^{82}$ The PTO itself entered a series of initiatives over the years, ${ }^{83}$ including the "peer-to-patent" pilot programs ${ }^{84}$ partial outsourcing of prior art searches, ${ }^{85}$ and setting policies to tackle the prevalence of false posi-

78 See 35 U.S.C. $§ 271$ (a), (e)(4)(B) (2012 \& Supp. V 2017) (entitles patent owners to exclude others from making, using, importing, selling, or offering to sell the invention).

79 See Helsinn Healthcare v. Teva Pharm. USA, Inc., 855 F.3d 1356, 1371 (Fed. Cir. 2017) (adopting a broad view of "on-sale," and concluding that "if the existence of [a] sale is public," then the invention fails the novelty test even if the details of the inventions are not publicly disclosed).

80 Frakes \& Wasserman, supra note 29, at 77-78 ("Concerns over the patent examination process have in part prompted Congress to enact the first major patent reform act in over 60 years, spurred the Supreme Court to take a more active interest in substantive patent law, and drove the USPTO to hold its first Patent Quality Summit.").

81 See Leahy-Smith America Invents Act, Pub. L. No. 112-29, §§ 6, 10, 125 Stat. 284, 299 316 (2011) (codified in scattered sections of 35 U.S.C.).

82 See KSR Int'l Co. v. Teleflex Inc., 550 U.S. 398, 420 (2007).

83 E.g., NAT'L ACAD. OF Pub. Admin., U.S. PATENT AND Trademark Office: Transforming to MeEt the Challenges of the 21st CENTURy 67 (2005) (showing that the agency committed significant resources to reviewing examiners' work); U.S. PATENT \& Trademark OfFice, Performance And Accountability Report 2, 11-12 (2003). In 2015, the PTO held a summit, seeking input to improve examination quality. See Patent Quality Summit, U.S. PAT. \& TRADEMARK OFF., http://www.uspto.gov/patent/initiatives/patent-qual ity-summit [https://perma.cc/R9X2-JY4G] (last accessed Oct. 5, 2019). The PTO can conduct studies and solicit public opinions under 35 U.S.C. § 2(b)(11) (2012 \& Supp. V 2017).

${ }^{84}$ The Peer to Patents project enabled the public to submit prior art to the PTO. See Press Release, U.S. Patent \& Trademark Office, USPTO Launches Second Peer to Patent Pilot in Collaboration with New York Law School (Oct. 19, 2010), available at https://www.uspto .gov/about-us/news-updates/uspto-launches-second-peer-patent-pilot-collaboration-newyork-law-school [https://perma.cc/B9ES-PAJB]; see also Daniel R. Bestor \& Eric Hamp, Peer to Patent: A Cure for Our Ailing Patent Examination System, 9 Nw. J. TeCh. \& InTElL. Prop. 16, 17-18 (2010); Christopher Wong \& Joseph Merante, Peer-to-Patent Year One: Potential for Implementation in Various Fields of Art Including Biotechnology, 5 ScITECH LAw., 26, 26 (2008). But see Erika Morphy, New Web Site May Smooth Patent Process, TECHNEwSWORLD (Mar. 6, 2007, 2:05 PM), http://www.technewsworld.com/story/software/ 56129.html?wlc=1294697010 [https://perma.cc/Z5WT-W5TV] ("The new system also favors large companies that routinely submit patent applications for approval.").

85 U.S. DEP'T OF COMMERCE, FY 2009 FISMA ASSESSMENT OF THE PATENT COOPERATION Treaty Search Recordation System (PTOC-018-00): Final Inspection Report No. 
tives. ${ }^{86}$ Yet, as the next Part shows, as long as the PTO remains centralized, such attempts do not address the core issues and can only provide limited relief.

\section{The CASE For A DeCEntralized PATENT Regime}

This Part sets forth the case for a decentralized patent system. I begin by analyzing the underpinning theoretical question: what are the criteria to decide between a centralized and a decentralized architecture? I show that centralized and decentralized systems are different in three main parameters: the decisionmaking outcomes, the information that the decisions are based upon, and the decision-making agents themselves. I show that in general, centralized systems are advantageous when uniform, precedent-based decisions are desired, and when agents' incentives are optimally set in an in-organization setting. On the other hand, when decisions include ad-hoc inquiries which produce diverse, fact-and-circumstance-specific results, and when the process can benefit from innovation in decision-making and from competition, a decentralized architecture would be preferable. Armed with this knowledge, I move to show that better results are forthcoming for the patent system in a decentralized structure.

The second Section below describes what a decentralized structure of the patent system may look like. As I expand below, under the proposed structure, the patent record would be decentralized, and would be fed with information by the PTO, patentees, industry players, and state actors during and after the examination process. Practitioners may also serve as patent examiners themselves. The PTO would retain the responsibility to review the patent record and fix errors. Finally, the third Section explicates the imminent advantages from the shift to a decentralized system.

\section{A. The Theoretical Framework}

As I show below, central operations differ from decentralized ones in three main parameters: the outcomes of their decision-making, the information that the decision-making is based upon, and the decision-making agents. Before I move to elaborate on these differences and discuss their suitability to the patent

OAE-19731 1 (2009), available at http://www.oig.doc.gov/oigpublications/oae-19731.pdf [https://perma.cc/95KE-AYDG] (last visited Oct. 6, 2019) (prior art searches and PCT patentability reports are performed by Cardinal IP, a private contractor). Opposition was voiced by the examiners' union. See Abramowicz \& Duffy, supra note 9, at 1573 n.110 (The opposition argued that privatizing search "represents a danger to the soundness of the patent system and the principles of integrity upon which it functions.") (internal quotation marks omitted).

86 See, e.g., Michelle K. Lee, Nominee for Dir., U.S. Pat. \& Trademark Off., Responses to Questions for the Record (Feb. 5, 2015), available at http://www.judiciary.senate.gov/imo/ media/doc/Lee\%20QFR\%202-5-15.pdf [https://perma.cc/4JJE-ERLU] (“[T]he USPTO has in place [quality controls] to ensure that only the highest quality patents are . . properly issued or properly denied."). But see The PTO's Cover-up of the Secret SAWS Program, AM. CTR FOR EQuitable TREATMENT (Aug. 8, 2018), http://acet-usa.org/the-ptos-cover-up-ofthe-secret-saws-program/ [https://perma.cc/VNB7-JCJL] (criticizing the Sensitive Applications Warning System (SAWS) as a quality assurance effort). 
system, an important qualifying statement is required. The issue I address in this Article - whether the patent system places excessive degree of power concentration with the PTO - must not be looked at from a paradigmatic prism. Neither centralization nor decentralization guarantees efficiency, fairness, or effectiveness. Centralized systems have some known costs. Similarly, decentralization has its costs. Therefore, as Craig Allen Nard and John F. Duffy argue in their seminal 2007 work, "a choice between a centralized and decentralized model cannot and should not be answered with a polar solution. The issue is one of optimization." $" 87$

Nard and Duffy's work focused on the centralization of patent judiciary powers with the Court of Appeals for the Federal Circuit. Based on their optimization approach, they argued for moderate decentralization, so that appellate jurisdiction over patent law would be allocated to more (but not many more) courts. ${ }^{88}$ For my purposes in this Article, I take a somewhat different approach with regards to balance and optimization. Rather than moderate decentralization, I argue for partial decentralization, namely decentralization of some of the functions of the patent system. Thus, while some examination and publication functions should be decentralized, the PTO should exclusively retain inter alia the powers of advising the President on intellectual property (IP) issues, issuing guidelines for patent examination, and conducting post-review procedures. ${ }^{89}$

\section{Outcome: Uniformity vs. Diversity}

Prime among the benefits of central operations is uniformity. Concentration of decision-making power within one agency raises the likelihood that the agency's decisions would share more commonality than decisions of dispersed decision-makers in a decentralized setting. ${ }^{90}$ This effect is a corollary inter alia to easier monitoring of decision-making under a centralized setting, to the likemindedness of agents in the same organization, and to the power of a central unit to maintain an archive of precedents, issue guidelines, and distribute them internally. ${ }^{91}$

87 See Craig Allen Nard \& John F. Duffy, Rethinking Patent Law's Uniformity Principle, 101 Nw. U. L. REv. 1619, 1624 (2007); see also R.H. Coase, The Nature of the Firm, 4 ECONOMICA 386, 390 (1937) (arguing in the context of firms' operations that both central and decentral operations have costs).

88 Nard \& Duffy, supra note 87, at 1625 ("We propose that, in addition to the Federal Circuit, at least one extant circuit court should be allowed to hear district court appeals relating to patent law. In addition, both the Federal Circuit and United States Court of Appeals for the District of Columbia Circuit (D.C. Circuit) should have jurisdiction over appeals from the PTO ....").

89 See, e.g., 35 U.S.C. § 2(b)(8)-(13) (2012 \& Supp. V 2017) (enumerating the various statutory duties of the PTO in advising the President, other executive branches, and congressional committees on intellectual property-related policy issues).

${ }^{90}$ Nard \& Duffy, supra note 87, at 1632.

91 Achieving uniformity was the goal of the creation of the Court of Appeals for the Federal Circuit back in 1981. See, e.g., S. REP. No. 97-275, at 5 (1981) ("The creation of the Court of Appeals for the Federal Circuit will produce desirable uniformity in this area of ... [patent] law."). Whether this end was actually achieved is a matter of debate. See, e.g., Glynn S. 
Uniformity has various salutary effects. ${ }^{92}$ First, uniformity increases certainty for market actors who face similar circumstances. ${ }^{93}$ Uniformity also reduces the costs of decision-making for the agency by enabling economies of scale, namely, applying decisions to new cases without incurring substantial additional costs. ${ }^{94}$ Uniform decision-making, however, carries drawbacks too. Uniformity discourages novelty and innovation in decision-making, limits opinion diversity, and restricts decision-makers' flexibility. Indeed, when an agency is committed to uniformity, less room is left for individual decisionmakers to produce diverse and innovative decisions. In decentralized operations, on the other hand, ideas can come from different agents with less constraints on their judgment.

Centralized operation is of course not synonymous with uniformity. Central organizations that rely upon different decision-makers are prone to de facto ununiform applications of their de jure uniform principles. In fact, the PTO may provide one of the best examples for a centralized institution that is internally inconsistent. ${ }^{95}$ Similarly, decentralized decision-making is not necessarily inconsistent with uniformity because other mechanisms may enforce uniform principles. ${ }^{96}$ Yet, as a general matter, it is a good rule of thumb to opt for a centralized system when the desired result is harmony and consistency, when the agency sees similar cases and can benefit from economies of scale, and when decisions are precedential. ${ }^{97}$ In contrast, a decentralized operation would be ad-

Lunney, Jr., Patent Law, the Federal Circuit, and the Supreme Court: A Quiet Revolution, 11 Sup. CT. ECON. Rev. 1, 76 (2004) (arguing that the Federal Circuit's precedents "have brought less certainty and predictability to patent enforcement" than expected).

92 See, e.g., John F. Duffy, Harmony and Diversity in Global Patent Law, 17 Berkeley TECH. L.J. 685, 686 (2002) ("Uniformity of law has an undeniable intellectual appeal.").

93 But see Gideon Parchomovsky \& R. Polk Wagner, Patent Portfolios, 154 U. PA. L. REV. 1, 40 (2005) (discussing how some Federal Circuit doctrines have actually produced "areas of expanding uncertainty").

94 See Nard \& Duffy, supra note 87, at 1636.

95 See Iain M. Cockburn et al., Are All Patent Examiners Equal? Examiners, Patent Characteristics, and Litigation Outcomes, in Patents In the Knowledge-Based Economy 19, 22 (Wesley M. Cohen \& Stephen A. Merrill eds., 2003) (finding that examinations' outcomes are strongly influenced by the examiner's identity); Michael D. Frakes \& Melissa F. Wasserman, Patent Office Cohorts, 65 Duke L.J. 1601, 1603 (2016) (“'[T]he PTO's decision to grant a patent application is driven not only by the merits of the invention but also by the proclivities of the examiner to whom the application is randomly assigned."); id. at 1639 (finding that the year examiners begin their service may have a lasting effect on their decision-making); Mark A. Lemley \& Bhaven Sampat, Examiner Characteristics and Patent Office Outcomes, 94 REV. ECON. \& STAT. 817, 821-22 (2012) (showing that examiners' experience influences the way they operate and their decision outcomes); Sean Tu, Luck/Unluck of the Draw: An Empirical Study of Examiner Allowance Rates, 10 STAN. TECH. L. REV. 1, 2 (2012) (finding that examination outcomes are strongly influenced by the examiner's identity).

96 See, e.g., Nard \& Duffy, supra note 87, at 1627 (noting that atomistic firms in a decentralized setting may "nevertheless produce[] a uniform market price because each firm is subject to the same economic forces").

97 See, e.g., supra note 91 and text accompanying footnote. 
vantageous when the desired outcome is to produce novel, diverse results based on relatively unrestrained judgment of agents. ${ }^{98}$

Under this criterion, the patent system is probably better suited for a decentralized regime than for a central one. Inventions that arrive at the PTO are unique in nature. Each patent represents a novel idea that has not been in existence before. ${ }^{99}$ Inventions also belong to diverse areas of science and technology, including interdisciplinary ones, esoteric ones, and ones that are novel and do not yet fit any known category. ${ }^{100}$ Examiners thus need to apply ad-hoc, flexible, independent judgment as to each particular invention. The unique and diverse nature of inventions also means that the decision-making process at the PTO is unlikely to benefit much from economies of scale. Attempts to apply economies of scale to patent applications may incentivize examiners to look for similarities rather than to focus on the individual characteristics of each invention.

This is not to say that uniformity is insignificant. Uniform application of patentability doctrines is important both to guide examiners and to increase inventors' certainty and trust in the system. ${ }^{101}$ Yet, concerns over uniformity cannot eclipse the main purpose of the patent examination - to compare between each invention and its scientific baseline and to identify those inventions that justify patents. ${ }^{102}$ Uniformity should be a feature of the system, but not its end. ${ }^{103}$ As I elaborate below, uniformity can be accomplished using training, guidelines, and regulation, as well as by post-review procedures by both the PTO and courts. ${ }^{104}$ With such mechanisms in place, concerns over uniformity should not be higher on a decentralized model than they are today. ${ }^{105}$

98 See Raaj Kumar Sah \& Joseph E. Stiglitz, The Architecture of Economic Systems: Hierarchies and Polyarchies, 76 AM. ECON. REv. 716, 716, 726 (1986) (discussing how centralized systems produce less ideas and less ideas of merit).

99 See 35 U.S.C. § 102(a)(1) (2012 \& Supp. V 2017); see also supra Section I.A.

100 See John R. Thomas, TAiloring the Patent System for SPecific Industries 3-4 (2015), https://fas.org/sgp/crs/misc/R43264.pdf (discussing the diversity of inventions and patents).

$101 C f$. Frakes \& Wasserman, supra note 95, at 1608 (discussing the concerns imminent to inconsistent examination).

102 See, e.g., In re Brouwer, 77 F.3d 422, 425 (Fed. Cir. 1996) ("The test of obviousness . . . requires that one compare the claim's 'subject matter as a whole' with the prior art."); In re Ochiai, 71 F.3d 1565, 1571 (Fed. Cir. 1995) (obviousness "requires a fact-intensive comparison of the claimed process with the prior art . . .."); Pfizer Inc. v. Teva Pharm. USA, Inc., 803 F. Supp. 2d 409, 441 (E.D. Va. 2011) ("Overall, the court must keep in mind that obviousness is a fact-specific inquiry ...."); Jonathan J. Darrow, The Patentability of Enantiomers: Implications for the Pharmaceutical Industry, 2007 Stan. TeCH. L. ReV. 2, I 24 (2007) ("[O]bviousness is a fact-specific inquiry."); see also Vishnubhakat, The Youngest Patent Validity Proceeding, supra note 4, at 344 ("To construe claims from the perspective of patent law's familiar 'person having ordinary skill in the art,' however, is a scientifically fact-intensive exercise ....").

103 See Nard \& Duffy, supra note 87, at 1620 ("[U]niformity is not a proxy for quality. That a policy is uniformly applied says very little about its soundness or desirability.").

104 See infra text in note 131.

105 For concerns over inconsistency under the current regime, see supra note 95, at 22. 


\section{Informational Foundations}

The desirability of centralized and decentralized systems also depends on the information that agents need in order to make good decisions. Centralized systems are advantageous when their decisions need to rely on institutional knowledge and when repeated decisions can be useful as precedents or guidelines. Thus, if the foundations for the decisions consist of prior cases, precedents, and institutional knowledge, then a centralized architecture has a clear benefit. On the other hand, decentralization would be superior when decisions rely on fact-gathering, ad-hoc circumstances, or exceptional knowledge, particularly when the knowledge is dynamic and frequently changing, because such knowledge is naturally dispersed in society rather than concentrated in one agency. ${ }^{106}$ Thus, the more fact-based and diverse the informational foundations are, and the more they concern discrete knowledge of ad-hoc circumstances and a diverse body of knowledge, the more strongly preferred decentralization would be.

What is the informational basis that is required for good patentability decisions? Patents naturally involve an extraordinarily broad range of technologies from all arrays of science. ${ }^{107}$ The information needed in order to assess all these inventions resides in the hands of individuals and companies all around the world, rather than being concentrated within any central examination unit. ${ }^{108}$ Further, patentability assessments demand detailed, fact-intensive inquiries into the invention and the state of the prior art. ${ }^{109}$ In fact, the one patentability requirement that does not require specific factual assessment-subject-matter eligibility - has often been criticized as redundant, except, perhaps, as an efficiency tool to deny patents in broad categories of inventions and free up resources for higher scrutiny of more promising ones. ${ }^{110}$ As discussed, a decentralized

106 As stated by Friedrich Hayek, "The economic problem of society is . . how to secure the best use of resources known to any of the members of society, for ends whose relative importance only these individuals know." FrIEDRICH A. HAYEK, The Use of Knowledge in Society, in INDIVIDUALISM AND ECONOMIC ORDER 77, 77-78 (1948); see also Nard \& Duffy, supra note 87, at 1631 ("Economists have long recognized the virtues of decentralized information gathering. Within economics there exists the basic assumption that having multiple information gathering points - multiple private actors operating in markets - allows for the generation of more complete and reliable data.").

107 See, e.g., Graham v. John Deere Co., 383 U.S. 1, 19 (1966); Dan L. Burk \& Mark A. Lemley, Policy Levers in Patent Law, 89 VA. L. Rev. 1575, 1650 (2003) ("Overwhelming evidence indicates that the application of the [person-having-ordinary-skill-in-the-art] standard varies by industry ....").

108 See supra note 106 and accompanying text.

109 John M. Golden, Patentable Subject Matter and Institutional Choice, 89 TEX. L. REV. 1041,1055 (2011) ("Patent law's requirements that an invention be novel, nonobvious, and adequately disclosed commonly demand detailed, fact-intensive inquiries into the state of the prior art; [and] the level of knowledge of one of ordinary skill in the art . . ."); see also sources cited supra note 102.

110 See, e.g., Pamela Samuelson \& Jason Schultz, "Clues” for Determining Whether Business and Service Innovations Are Unpatentable Abstract Ideas, in PERSPECTIVES ON Patentable Subject Matter 8, 13 (Michael B. Abramowicz et al. eds., 2015) (arguing that 
setting would have a powerful advantage in data-collection regarding industryspecific facts, trends, problems, and solutions. ${ }^{111}$

Finally, the informational basis for patent examination also includes legal doctrines. Indeed, patentability criteria, while based on factual foundations, are themselves legal conclusions. ${ }^{12}$ Claim construction is also a "purely legal" issue. ${ }^{113}$ Legal knowledge would not be more pronounced in a central operation. PTO examiners are not lawyers. ${ }^{114}$ They rely on the PTO guidelines when they apply legal doctrines, prior cases, and institutional knowledge. Decentralized operations can more naturally receive legal input when needed and can obviously continue to rely on the PTO's training and guidelines.

subject-matter inquiries can increase the efficiency of USPTO and court proceedings by eliminating broad categories of cases); Tun-Jen Chiang, The Rules and Standards of Patentable Subject Matter, 2010 WIS. L. REV. 1353, 1403 (2010) ("[L]ayers of screening make sense in order to reserve detailed scrutiny for a subset of cases"); John F. Duffy, Rules and Standards on the Forefront of Patentability, 51 WM. \& MARY L. REV. 609, 623 (2009) ("[I]t should be a rare situation in which an entire class of patents complies with the nonobviousness requirement and yet still somehow discourages or impedes the development and spread of useful knowledge."); Kristen Osenga, Ants, Elephant Guns, and Statutory Subject Matter, 39 ARIZ. ST. L.J. 1087, 1092 (2007) ("[T]he question of subject-matter eligibility for any invention is essentially pro forma, and whether a patent is granted ... should be based on the application meeting the requirements of patentability provided by 35 U.S.C. $\S \S 102,103$, and 112."); Michael Risch, Everything is Patentable, 75 TenN. L. REv. 591, 658 (2008) ("[T]he PTO and courts should focus on answering specific questions about how to best apply rigorous standards of novelty, nonobviousness, utility, and specification with a scalpel rather than simply eliminating broad swaths of innovation with a machete."); John R. Thomas, The Responsibility of the Rulemaker: Comparative Approaches to Patent Administration Reform, 17 BERKELEY TECH. L.J. 727, 734 (2002) ("Until recently, subject matter limitations provided a less time-consuming mechanism [than other patent criteria] for the USPTO to reject applications."); Aaron J. Zakem, Note, Rethinking Patentable Subject Matter: Are Statutory Categories Useful?, 30 CARDOZO L. REV. 2983, 2988 (2009) (describing subjectmatter eligibility as "distracting the court from analyzing other requirements for patentability such as utility, novelty, non-obviousness, and enablement").

111 See supra note 106 and accompanying text.

112 See, e.g., Aktiebolaget Karlstads Mekaniska Werkstad v. U.S. Int'1 Trade Comm'n, 705 F.2d 1565, 1575 (Fed. Cir. 1983) ("Obviousness is a legal conclusion based on factual determinations and not a factual determination itself.") (citations omitted). For the nature of the obviousness doctrine as a standard rather than a rule, see Michael J. Burstein, Rules for Patents, 52 WM. \& MARY L. REV. 1747, 1774 (2011) ("[A] pure standard is optimal [for the obviousness doctrine] ... ."); see also KSR Int'l Co. v. Teleflex Inc., 550 U.S. 398, 415 (Fed. Cir. 2007) (favoring an "expansive and flexible approach"). For more general discussions of rules and standards in patent law, see Rochelle Cooper Dreyfuss, The Federal Circuit: A Case Study in Specialized Courts, 64 N.Y.U. L. REV. 1, 8-10 (1989) (discussing legal rules and standards); Duffy, supra note 110, at 610-53; John R. Thomas, Formalism at the Federal Circuit, 52 Am. U. L. Rev. 771, 792 (2003).

113 See, e.g., Cybor Corp. v. FAS Techs., Inc., 138 F.3d 1448, 1456 (Fed. Cir. 1998) (en banc) (holding that claim construction is a "purely legal question").

114 See, e.g., U.S. Pat. \& Trademark Off., Engineers \& Scientists: Job Announcement Just Opened for Patent Examiners, https://www.uspto.gov/sites/default/files/documents/Exam iner\%20brochure\%202018\%20downloadable.pdf (last visited Dec. 19, 2019). 


\section{Decision-makers}

Another area where centralized and decentralized forms differ concerns the decision-making agents. Centralized organizations typically rely on the work of employees. Conversely, decentralization enables flexible ad-hoc enlisting of agents based on the current workload and the proficiency that is required for the task in hand. Decentralization also enables self-selection of agents to projects, while a centralized setting typically calls for top-down work assignments. ${ }^{115}$ Relatedly, the compensation and incentives of decision-makers are paradigmatically different between centralized organizations and decentralized ones. In most cases, in a centralized setting, agents are salaried employees who are incentivized by inner-organization incentives, such as promotions and pay raises. Decentralized settings, on the other hand, enable differential compensation schemes, from per-project payments, to salaries and non-monetary compensation. ${ }^{116}$

Some types of tasks are perfectly suitable for inner-organization incentives. Salaried employees can perform the work that is assigned to them in a predictable manner and timeframe and adhere to set guidelines. ${ }^{117}$ The availability of a known number of agents also enables the organization to plan its workload, set quotas, and monitor agents. This structure is suitable to tasks that are known in advance, that are similar to each other, and that require similar resources and timeframes to resolve. Other tasks are a better fit for a more flexible deployment and compensation scheme, such as when diverse skillsets are required and when the scope of work and the resources it entails are beyond the immediate control of the agency and cannot be anticipated in advance.

Decentralized architectures also more naturally foster competition between decision-making agents. ${ }^{118}$ Of course, centralized systems can inject some level of internal competition between actors, and some decentralized systems fail to generate competition at all. Yet, generally, there is less room for competition in central systems, where the allocation of tasks, time, and resources are set top down, leaving little control for individual agents. This conclusion also stems from the uniform nature of the centralized structure, because competition is more likely when actors can operate freely and reach diverse results than when they are required to follow precedents and generate uniform outcomes. ${ }^{119}$

Competition can be desired in some cases and unwelcome in others. In suitable cases, competition can generate incentives for actors to work more efficiently, improve, and yield better results. ${ }^{120}$ In cases that are not fitting, com-

\footnotetext{
115 See, e.g., supra note 16 and accompanying text (explaining how inventions are routed to examiners).

116 See infra Section III.B.

117 See, e.g., infra note 124 and accompanying text.

118 See, e.g., Nard \& Duffy, supra note 87, at 1629 ("[C]ompetition provide[s] a powerful justification for decentralized decision-making.").

119 See, e.g., Juan D. Carrillo \& Denis Gromb, Cultural Inertia and Uniformity in Organizations, 2006 J.L., ECON., \& ORG. 1, 1, 24.

120 See id. ("Competition serves as an important check on poor decisions.").
} 
petition can produce waste, such as when it prevents cooperation between agents and leads to duplicate efforts. ${ }^{121}$ When deciding between central and decentralized settings, it would thus be helpful to identify whether the case in hand can benefit from competition more than suffer from its associated costs.

What system would allow to recruit, incentivize, and retain better agents to perform patent examination? A centralized regime, such as the PTO, features full-time patent examiners. ${ }^{122}$ The PTO even forbids examiners from receiving outside input regarding obviousness. ${ }^{123}$ The main problem with this approach is that it limits examination to the skillset of the one examiner that the invention is routed to. A decentralized structure could welcome outside input of various kinds to complement or substitute examiners' skillsets based on dynamic needs of volume and knowledge.

Consider now the incentives of patent examiners to make good decisions in a centralized and in a decentralized regime. The PTO arguably falls short in measuring and incentivizing employee performance. ${ }^{124}$ Granted, many obstacles that the PTO faces stem not from its central operation per se, but from its public sector status. Government agencies notoriously have a harder time motivating employees than firms in the private sector. ${ }^{125}$ Among other things, government employees' salaries are independent of market forces, and employees are difficult to dismiss, ${ }^{126}$ especially when protected by strong unions, such as the PTO employees' union. ${ }^{127}$ The PTO system for incentivizing examiners is a

121 See id. ("Competition ... can lead to wasteful strategic behavior.").

122 See General Information Concerning Patents, U.S. PAT. \& Trademark OfF. (Oct. 2015), https://www.uspto.gov/patents-getting-started/general-information-concerning-patents

[https://perma.cc/2F4A-SGWK] (describing the structure of the PTO and noting that "the USPTO has over 11,000 employees, of whom about three quarters are examiners and others with technical and legal training").

123 See 35 U.S.C. § 122(c) (2012 \& Supp. V 2017); see also 37 C.F.R. § 1.290 (2019).

124 See Lisa Rein, Patent and Trademark Office Doesn't Know if Examiners are Doing Their Jobs, Watchdog Says, WASH. Post (Apr. 14, 2015), https://www.washingtonpost.com/news/ federal-eye/wp/2015/04/14/the-u-s-patent-and-trademark-office-doesnt-know-if-patentexaminers-are-doing-their-jobs-watchdog-says/?noredirect $=$ on\&utm term $=.985 \mathrm{cfe} 589 \mathrm{f} 3 \mathrm{a}$ [https://perma.cc/D8DM-HDUZ] (reporting that the PTO does not ensure that examiners work adequately).

125 See James Q. Wilson, Bureaucracy: What Government Agencies Do And Why THEY Do IT 125 (1989) (noting that agencies do not have a powerful profit motive, and public sector managers are not "task-oriented"); Abramowicz \& Duffy, supra note 9, at 1551 ("[W]hen it comes to tasks like measuring employee performance, the public sector is unlikely to be as effective as the private sector.").

126 See Stewart Liff, Managing Government Employees: How to Motivate Your People, Deal with Difficult Issues, and Achieve Tangible Results 8-9 (2007) (explaining how government employees enjoy better job security than private sector employees).

127 Government unions have become stronger as private-sector unionism has declined. See Panel Discussion, Living with Privatization: At Work and in the Community, 28 FordHAM URB. L.J. 1397, 1406 (2001) ("Union membership is more than four times as high in government as in the private sector."); see also Leo Troy, Are Municipal Collective Bargaining and Municipal Governance Compatible?, 5 U. PA. J. LAB. \& EMP. L. 453, 457-58 (2003) ("[O]rganized public employees are generally more highly paid than organized private union members."). 
case in point. The PTO implemented a system for measuring examiners' productivity in $1976 .{ }^{128}$ The system was slightly revised in 2004, but the principles have remained the same: examiners receive "counts" for completion of tasks, which translate to bonuses. ${ }^{129}$ The program has attracted vast criticism, such as that it has skewed incentives for examiners and that some of its goals have been too easy to reach. ${ }^{130}$ The main problem with the current incentive system, however, is that examiners' incentives are not tied to quality. Most profoundly, examiners' pay is not affected by an event where the examiner's decisions have been upheld or nullified by post-review procedures at the PTO or by courts. ${ }^{131} \mathrm{~A}$ decentralized regime can more effectively generate a competitive compensation scheme based on performance and proficiency. In Part III below I portray a blueprint for such a system.

\section{B. How a Decentralized Patent System Would Work}

There is more than one way to construct a decentralized patent system. A prominent contribution to this literature includes Michael Abramowicz and John F. Duffy's proposal to license private examination firms to compete with the PTO on conducting examinations. ${ }^{132}$ While their model is promising in terms of productivity and competition in the examination process, it retains the ineffectiveness of the patent record and the concentration of decision-making with individual patent examiners. New developments in database technology now enable other forms of decentralization.

Under the decentralized model that I consider in this Article, inventors would submit patent applications to a shared patent record instead of filing them with the PTO. After a grace period, in which inventions would remain secret, the record would be open to the public and the patent examination process would ensue, with the participation of the patent community. Following the examination, granted patents would be published to the patent record, which would remain dynamically updated throughout the lifetime of the patent. The PTO would take an active part in setting guidelines ex ante, maintaining the accuracy of the record, and conducting post-review procedures ex post.

The new patent database can be built on a blockchain or on another platform that enables autonomous sharing of information by participants. Block-

128 NAT'L ACAD. OF PUB. AdMin., supra note 83, at 99 ("The basic awards structure for patent examiners has been in place since 1976.").

129 The accumulation system of "counts" varies between departments and upon the seniority of the examiners. Junior examiners, for example, are measured mainly according to responsiveness to applicants and are thus incentivized to generate many communications. See, e.g., Tu, supra note 95, at 7; see also The Examiner Count System: Why Patent Examiners Are on Your Side, NuTter (Nov. 18, 2014), https://www.nutter.com/ip-law-bulletin/the-examinercount-system-why-patent-examiners-are-on-your-side [https://perma.cc/4AQK-MQ8A].

130 For example, examiners have an incentive to issue "final" rejections that are not at all final, because it generates a "count," even though this act increases the costs for patentees who need to correspond with the agency.

131 See infra Section III.B.

132 See Abramowicz \& Duffy, supra note 9, at 1543-44. 
chains are a type of distributed data containers that enable recording transactions without central management or intermediaries. ${ }^{133}$ What makes blockchain a good candidate for the purpose of patent registration is its decentralized, distributed nature, which can enable registration of patents, sharing robust information about them, and commercializing them autonomously. Yet, this Article explicitly shuns from relying on any particular technology. New technologies can be developed in the future that would be as - if not more-fitting for this task.

Below I elaborate on the two stages of the patent lifespan under a decentralized regime: the examination process and the post-examination stage. I also discuss mechanisms to mitigate some of the costs that decentralization may entail. In particular, such mechanisms aim to ensure consistent application of patentability criteria during the examination, incorporate knowledge and experience into the examination process, and ensure the reliability of the patent record.

\section{The Examination Process}

The basic concept of decentralized patent examination is that the examination process would be open and participatory and allow input by various parties throughout the process. There is a continuum of options regarding the way a decentralized examination process could be constructed. On the one end of the spectrum, it is possible to keep the examination process in the hands of PTO examiners, and merely allow them to benefit from robust input. On the other end of the spectrum, a bolder option would be to privatize the examination itself, so that the first line of examiners would comprise of industry experts who would themselves review patent applications and make prima facie patentability decisions. ${ }^{134}$

The main advantage of full privatization is to harness the vast expertise of industry experts in diverse fields of science. Industry-based examiners embody the PHOSITA standard themselves and are more likely than PTO examiners to

133 For the origin of blockchain and technological background, see ARVIND NARAYANAN ET

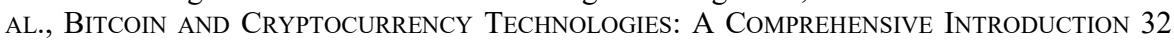
(2016); see also Primavera De Filippi \& Aaron Wright, Blockchain and the LaW: The Rule of Code 30 (2018); Don TAPscott \& Alex Tapscott, BlockChain Revolution: How the Technology Behind Bitcoin is Changing Money, Business, AND the World 56 (2016); Jean Bacon et al., Blockchain Demystified: A Technical and Legal Introduction to Distributed and Centralised Ledgers, 25 RicH. J.L. \& TECH., 1, 4-5 (2018).

134 Intermediate options on this continuum could, for example, draw on Abramowicz and Duffy's proposal, and allow private examination firms to perform the examination, rather than to refer all inventions to the PTO. It would be possible to use the competitive mechanism Abramowicz and Duffy propose in order to direct inventions to examiners, or to enable the system itself to direct inventions to different firms. The second option would create competition between firms with regard to hiring of examiners but would not allow inventors to select the examining firm, thus avoiding race-to-the-bottom concerns that Abramowicz and Duffy contended with in their original piece. See Abramowicz \& Duffy, supra note 9, at $1573,1577$. 
identify inventions unworthy of patents. ${ }^{135}$ On the other hand, maintaining patent examination at the PTO has advantages as well, including consistency and experience with the examination process, lower (though not nonexistent) concerns of biases, and advantages that stem from the fact that this is the system already in place. Under both options, from the point of view of patent applicants, the patent prosecution process would be rather similar to the extant process. I propose no changes to patentability criteria, to patent doctrines, nor to post review procedures at the PTO or the appeal procedures in the court system. ${ }^{136}$

Let us delve deeper into the choice between a more-or-less bold decentralization of the examination process. Under the option of examination by PTO examiners, patent applications would be public, allowing third parties to share information regarding the invention that can be relevant for the examination process. The patentability decision itself, however, would remain in the hands of PTO examiners. This idea goes hand in hand with initiatives by the PTO to receive information from the public, ${ }^{137}$ as well as with Rebecca Eisenberg's idea to allow subject-matter experts to weigh in on obviousness, ${ }^{138}$ although it is clearly more expansive than these initiatives, by allowing more kinds of input and by establishing autonomous, public submissions.

The information that is relevant for the examination process would concern patentability criteria. In particular, third parties' input regarding novelty and obviousness could be of great value. ${ }^{139}$ Novelty is inevitably assessed by exam-

135 See supra Section I.B.

136 Some procedural changes may nevertheless be considered. A good candidate is implementing an anonymous review. The identity of inventors is irrelevant to the patentability of the invention. In fact, some scholarship indicates that the identity of the inventor may bias PTO examiners towards allowing more patents of repeat players and rejecting more patents of disadvantaged social groups. See AdAms Nager et AL., The Demographics of INNOVATION IN THE UNITED STATES 6 (2016) (noting that minorities hold only $8 \%$ of U.S. patents); Kyle Jensen et al., Gender Differences in Obtaining and Maintaining Patent Rights, 36 NAtURe Biotechnology 307, 307-09 (2018) (finding that women are less likely to have their patent applications approved, especially when their gender can be guessed by their names on the application); see also INST. FOR WOMEN'S POL'Y RES., INNOVATION AND INTELLECTUAL PROPERTY AMONG WOMEN ENTREPRENEURS 12 (2018), https://iwpr.org/wpcontent/uploads/2018/07/C472_Report-Innovation-and-Entrepreneurship-9.6.18-clean.pdf

[https://perma.cc/7MTC-73ND] (finding that underrepresentation of women as patentholders is most pronounced among women of color). On the other hand, anonymization may not be effective- especially in industries where the identity of the inventor can be guessed.

137 See, e.g., supra note 84 and accompanying text.

138 See Eisenberg, supra note 50, at 898.

139 Other patentability criteria are more technical and can be decided by the examiner and perhaps, as technology progresses, by Artificial Intelligence (AI). Whether patentability decisions could be transformed into code (in the form of AI) needs to be carefully examined both legally and empirically. Indeed, "[a] central promise of AI is that it enables large-scale automated categorization." See, Jonnie Penn, AI Thinks Like a Corporation-And That's Worrying, ECONOMIST: OPEN FUTURE (Nov. 26, 2018), https://www.economist.com/openfuture/2018/11/26/ai-thinks-like-a-corporation-and-thats-worrying [https://perma.cc/7DDECGH3]. But this ability is a gain for some patentability criteria but a burden to others. For example, AI should be able to tell the difference between patentable and non-patentable sub- 
iners based on incomplete information, and third parties' input can shed light on otherwise unknown instances where the invention was offered for sale or disclosed publicly. ${ }^{140}$ The obviousness assessment can also gain from input by third parties who are immersed in the technology more than PTO examiners.

Besides the benefits to the examination quality, an open record can also boost productivity. Granted, the system would create voluminous information regarding many patents, which the examiners would need to review. Yet, examiners would not need to waste time on searching for information that is readily at hand for third parties and would likely also face fewer objections and disputes ex post. Clearly, for this option to work, guidelines that define confidentiality, responsibilities, and liabilities for providing information on the record must be set. I address these issues in Part III below.

The second option, privatization of the examination process, would more dramatically revolutionize the examination process. It would require a list of preapproved examiners to be composed for each area of technology. The preselection should be conducted by the PTO after reviewing education and knowledge criteria. ${ }^{141}$ As in today's regime, patentability decisions would not be conclusive or unassailable. The PTO would be able to reverse unsound decisions and to consider decertifying examiners that issue too many unjustified patentability opinions. ${ }^{142}$ The PTO would also be responsible for promulgating guidelines that provide its interpretation of law that patent examiners would

ject matter at least as easily as human examiners do. Yet, broad categorization may prove counter-productive for determining obviousness or lead to biases in favor of or against certain types of inventions, inventors, or fields. Whether this happens depends first and foremost on the quality of the dataset that the algorithm is trained upon. AI algorithms can only mirror the decisions of human examiners that the algorithms were trained upon. The dataset used to train the model must be reasonably accurate and bias-free. Implementing AI for patent examination can achieve scale and speed beyond human capabilities. Scale and speed should not, however, come at the expense of accuracy, integrity, accountability, or other values that are inherent to the patent examination process. The application of AI for patent examination is thus speculative at this stage.

140 This is particularly true under the new Helsinn decision, which holds that secret agreements can also preclude novelty. Helsinn Healthcare v. Teva Pharm. USA, Inc., 855 F.3d 1356, 1371 (Fed. Cir. 2017).

141 It is possible to use the same criteria that are used today to hire PTO examiners and potentially complement them with the requirement that the candidate have knowledge as to the examination process. See generally Join the United States Patent and Trademark Office, USAJOBS, https://uspto.usajobs.gov/ [https://perma.cc/5VDT-JS3N] (searching by keyword: "Patent Examiner") (last accessed Nov. 15, 2019).

142 See infra Section III.B. What is more, even if examiners are generally professional and ethical, they may be unfit to examine some particular inventions. Conflicts of interest, special relationships, or other reasons may compromise the integrity of the examination process. Knowledge of such conflicts naturally resides with the inventors and potential examiners more than with the PTO or with whatever automatic selection system that would be put in place. As a result, inventors should be able to deselect examiners from reviewing their invention, as is practiced in other peer to peer processes as well such as grant review. Examiners should also have the ability to withdraw from examination, but only until they were exposed to the invention. 
need to adhere to. ${ }^{143}$ Guidelines can be issued in the form of manuals, examples, training materials, and forums, ${ }^{144}$ as well as policy studies ${ }^{145}$ and procedural guidelines. ${ }^{146}$ The PTO issues guidelines for patent examiners under the extant regime as well. But the importance of guidelines would be greater under a fully decentralized regime. There, the guidelines would be a key vehicle to inject uniformity into the system and to bring in institutional experience that comes with the exposure to numerous cases.

Under a fully decentralized regime, the PTO should also be responsible for the training of new and continuing examiners. The training of PTO examiners shifted in 2006 from a modest two-week program to a more robust one with the opening of the Patent Training Academy. ${ }^{147}$ Today, patent examiners are subject to two months of extensive training upon entering the office, and an additional six months of training while working, before they fully transition into art

143 The PTO has natural powers to issue such guidelines. See, e.g., Metro. Sch. Dist. of Wayne Twp. v. Davila, 969 F.2d 485, 490 (7th Cir. 1992) (“All agencies charged with enforcing and administering a statute have "inherent authority to issue interpretive rules informing the public of the procedures and standards it intends to apply in exercising its discretion." ").

144 See, e.g., Examination Guidelines for Determining Obviousness Under 35 U.S.C. 103 in View of the Supreme Court Decision in KSR International Co. v. Teleflex Inc., 72 Fed. Reg. 57,526 (Oct. 10, 2007); U.S. Patent \& Trademark Office, Analyzing Nature-Based PRODUCTS: TRAINING MANUAL (2015), https://www.uspto.gov/sites/default/files/documents/ $101 \mathrm{JE}$ training Nature-Based Products Module.pdf [https://perma.cc/2MSX-T6M4]; U.S. Patent \& TRAdEMARK OfFice, EXAMPles: AbSTRACT IDEAS (2014), https://www.uspto.gov/ sites/default/files/documents/abstract_idea_examples.pdf [https://perma.cc/UQ9Z-H4GN]; U.S. Patent \& Trademark Office, Nature-Based Products Examples (2014), https://www.uspto.gov/sites/default/files/documents/mdc_examples_nature-based_products. pdf [https://perma.cc/AX5Y-RJHY]; Forum on Patent Subject Matter Eligibility, U.S. PAT. \& TRADEMARK OFF. (Jan. 21, 2015), https://www.uspto.gov/patent/laws-and-regulations/ex amination-policy/january-21-2015-forum-patent-subject-matter [https://perma.cc/B5TPFWF3].

145 See Leahy-Smith America Invents Act, Pub. L. No. 112-29, §§ 26, 27, 29, 31, 125 Stat. 284, 338-39 (2011) ("Study on Implementation," "Study on Genetic Testing," "Establishment of Methods for Studying the Diversity of Applicants," and "USPTO Study on International Patent Protections for Small Businesses," respectively).

146 The PTO sets its own procedures. See 35 U.S.C. § 2(b)(2)(A) (2012 \& Supp. V 2017) (authorizing the PTO to make rules "govern[ing] the conduct of proceedings in the Office"); see also Golden, supra note 109, at 1044 (noting that the PTO "possesses binding rulemaking authority with respect to procedural aspects of USPTO activities, such as patent examination, issue, and reexamination").

147 Frakes \& Wasserman, supra note 95, at 1620-21. Compare U.S. Gov'T Accountability Off., GAO-07-1102, U.S. Patent and Trademark OfFice: Hiring EfForts are Not Sufficient to Reduce the Patent Application Backlog 10 (2007), and Annemarie L.M. Field et al., Patent Examiner Recruitment: An Interactive Qualifying Project for the USPTO 71 (Dec. 12, 2007), (unpublished B.S. thesis, Worcester Polytechnic Institute) (available at http://citeseerx.ist.psu.edu/viewdoc/download?doi=10.1.1.455.7037

\&rep=rep1\&type=pdf [https://perma.cc/5RTV-J9RZ]), and U.S. PAT. \& TradeMARK OfF., Performance AND ACCOUNTABILITy Report 101-03 (2002), with U.S. PAT. \& TRAdemark OfF., Performance And Accountability Report 4 (2006), and Field et al., supra. 
units. ${ }^{148}$ Examiners keep receiving training, guidelines, and updates during their service. ${ }^{149}$ Under the new regime, it would probably be neither practical nor necessary to train scientist-examiners in "college-like lectures." 150 Some of the content in this training is also less relevant when the system shifts from a public service to a decentralized system. ${ }^{151}$ Instead, the training should be given mostly remotely and continue during examination. ${ }^{152}$ It is also possible to initiate a period of review, perhaps similar to the second-pair-of-eyes review that the PTO applied for new examiners, where current PTO-examiners would review the work of industry examiners in the first period. ${ }^{153}$

Patent examination by industry practitioners would resemble other areas, such as journal publications and grants, that use peer review to determine the novelty and contribution of scientific research. ${ }^{154}$ Peer review in these areas has attracted criticism, mainly over biases and conflicts of interests. ${ }^{155} \mathrm{I}$ am sensitive to these concerns and will address them in Part III below.

\section{Post-Examination}

Under a decentralized system, the record would remain a live platform throughout the lifetime of the patent and would be updated with information from various market and state actors, including patentees, patent examiners, licensees, the PTO, and courts. The record could then entail all the information

148 See Frakes \& Wasserman, supra note 95, at 1620-21. See generally Examination Guidance and Training Materials, U.S. PAT. \& TRADEMARK OFF., https://www.uspto.gov/patent/ laws-and-regulations/examination-policy/examination-guidance-and-training-materials [https://perma.cc/VM4B-MEM7] (last visited Oct. 19, 2019).

149 See generally Examination Guidance and Training Materials, supra note 148.

150 See Frakes \& Wasserman, supra note 95, at 1621.

151 Less relevant content includes, for example, soft skills regarding service and work-life balance. See, e.g., Join Us, U.S. PAT. \& TRADEMARK OFF., https://www.uspto.gov/jobs/joinus?utm_campaign $=$ cio-jobsf5\&utm_source $=$ f5redir\&utm_medium=direct [https://perma.cc/ DZ85-WXEX] (detailing the content of the training materials) (last visited Oct. 19, 2019).

152 See, e.g., U.S. Pat. \& Trademark Off., Legal Analysis and Writing Part II: How to Evaluate And Analyze Legal Arguments Based on CASE Law 3 (2017), https://ww w.uspto.gov/sites/default/files/documents/partii_legalworkshop_slides01.pdf [https://perma. $\mathrm{cc} / 83 \mathrm{AQ}-\mathrm{FRVD}]$ (stating that the training aims to "[b]ring consistency to responding to Applicant's arguments based on case law ....").

${ }_{153}$ See Gene Quinn, Alice Experts and the Return of Second Pair of Eyes to the PTO, IPWATCHDOG (July 24, 2016), https://www.ipwatchdog.com/2016/07/24/alice-experts-sec ond-pair-of-eyes/id=71185/ [https://perma.cc/6SZL-F4UB] ("[I]n about 2002, the Patent Office instituted what they referred to as 'second pair of eyes' review. Under no circumstances could a patent be issued on anything that related to a computer-implemented invention unless and until it had been approved by two separate patent examiners.").

154 See Eisenberg, supra note 50, at 902-03 (noting that input from industry players in the patent process "suggest[s] parallels to two other peer review systems ... : peer review of submitted articles for scientific journals and peer review of grant proposals for sponsors").

155 See, e.g., Fiona Godlee \& Kay Dickersin, Bias, Subjectivity, Chance, and Conflict of Interest in Editorial Decisions, in PeER Review in Health Sciences 91, 107-09 (Fiona Godlee \& Tom Jefferson eds., 2d ed. 2003); David F. Horrobin, The Philosophical Basis of Peer Review and the Suppression of Innovation, 263 JAMA 1438, 1438, 1441 (1990). 
[Vol. 20:1

about inventions from the existing patent registries, augmented with information that the PTO does not have access to. Information from all parties could be fed into the record autonomously, rather than by the PTO. Decentralizing the power to insert information into the database can turn the record into an up-todate, useful, and dynamic database.

Information that can make the record more useful can be divided into three categories: technological information, transactional information, and legal information. Technological information typically resides with patent applicants or with third parties. Some of this information is submitted with the application, such as explanation of the know-how and prior art. ${ }^{156}$ Unlike today, this information should be fully included in the record. ${ }^{157}$ Moreover, knowledge continues to develop in the area of the patent by the patentee and by third parties after the filing of the application. As more information is constantly created, there is no reason to limit the information on the record to the time the patent was filed. Patentees and third parties should be able to add scientific publications, developments, related patents or products, and other materials to the record. ${ }^{158}$

Transactional information could also be shared by patentees. Once the patent record is decentralized, patentees would be able to include licensing options, potential use cases, and "call for proposals" for potential licensees. Absent any contradictory term in contracts, licensees should also be able to add license information. Patentees must be under an obligation to present only updated and available licensing options, in order to prevent misrepresentations and ensure reliance on the record. Beyond licensing, patentees would be able to plug in smart contracts and allow third parties to automatically act on available licenses. ${ }^{159}$ Indeed, on a decentralized platform, rights in the patent bundle can

156 See 35 U.S.C. § 112(a) (2012 \& Supp. V 2017); 37 C.F.R. § 1.56 (2018).

157 Some technical information that patentees have is never filed or shared-in or beyond the patent prosecution process. A good example of such information could be what Michal Shur-Ofry dubbed "negative information." See Michal Shur-Ofry, Access-to-Error, 34 CARdozo ARTS \& ENT. L.J. 357, 369 (2016). This term refers to errors, failures, and additional types of such information, which, if disclosed, can boost knowledge and prevent waste by avoiding repeating futile efforts by multiple scientists. See id. at 399-400. Some of this information is rightly held by the inventor as trade secrets. See, e.g., Charles Tait Graves, The Law of Negative Knowledge: A Critique, 15 Tex. InTELL. Prop. L.J. 387, 388-89 (2007) (describing and criticizing the protection of negative knowledge under trade secret law). Yet, it is worth considering expanding the disclosure responsibilities of patentees and compel or incentivize them to submit for public knowledge more than what is required today. There is, of course, also, a negative side for compelling too much disclosure, in terms of cost, trade secrecy, and efficiency, as too voluminous information can be excessive, and harm, rather than assist, the usefulness of the record.

158 Some information can also be added automatically as part of the functionality of dynamic databases. Thus, the system would be able to link from patent entries on the database to similar other items on the database in a more simplified manner than what is available on the current static record. It may also be possible to link this information to other databases, such as prior art databases.

159 Rules to bridge the gap between smart contracts, which are basically software, and contracts in the legal terms, are yet to be set to ensure enforceability and acceptance of this technology in this and other contexts. See Pierluigi Cuccuru, Beyond Bitcoin: An Early Overview on Smart Contracts, 25 INT'L J.L. \& INFO. TECH. 179, 194-95 (2017). 
each be owned and exploited separately without generating excessive transaction costs. Decentralization would thus transform the patent record from a static information board to a dynamic commercialization platform for inventions. ${ }^{160}$

Finally, legal information can add value to the record on two main levels. First, advanced search and contextual connections can spot potential infringements - later appearances in the record that are similar to the invention-and bring them to the attention of patent owners. This functionality would also incentivize patent owners to list detailed and specific information about their invention, and so receive specific infringement alerts.

Another relevant legal material includes litigatory information of patents. As discussed above, under today's regime, finding litigatory information of a patent is nontrivial. ${ }^{161}$ Concentrating litigatory information within the patent record can produce a more comprehensive picture of patents and their uses. It would be possible to learn whether the patent or particular claims of it are in question, whether the patentholder is prone to litigation, and other useful information, which is costly to obtain under the extant regime. There are two ways to include litigatory information within the record. It is possible to require applicants to submit updates when a lawsuit is filed. Yet, it would probably be more reliable and efficient that the record would be automatically updated whenever a court case cites a patent. Patentees and third parties should be able - but not forced - to share information about out of court settlements or other such updates.

While the strength of this model lies in expanding the entities who can insert information into the patent record, this feature of the model can also become a source of concern. The concern is that without central management, the record may become riddled with errors, irrelevant information, and inconsistent structure that would be difficult to navigate. While this concern sounds alarming at first sight, it is in fact relatively easy to tackle with a combination of system design, rules and liabilities, and error-correction mechanisms. Let us begin with system design. Importantly, blockchain technologies - and their equivalents-have built in capabilities to track the actions that are taking place in the system. ${ }^{162}$ This feature of the system would make it possible to find the source of errors, correct them, and prevent them from reappearing. It also allows for taking measures against parties for inserting intentional misleading information in the file. ${ }^{163}$ Also, an important feature of the system is empowering the PTO to correct errors on the record. ${ }^{164}$ Open questions remain as to rules and incen-

160 But see Michael J. Burstein, Patent Markets: A Framework for Evaluation, 47 ARIz. ST. L.J. 507, 512-13 (2015) ("[T]ransactional efficiency in itself is neither the goal of the patent system nor of financial markets.").

161 See supra note 78 and accompanying text.

162 See supra note 138 and accompanying text.

163 See infra Section III.C.

164 Such systems, where information can be shared by various bodies and moderated to correct mistakes, are very common in many contexts - from internet sites with user generated content, to navigation systems and online maps, to other systems. See What is the Difference Between a Blockchain and a Database?, COINDESK, https://www.coindesk.com/information/ 
tives regarding how information can be fed to the blockchain (or equivalent databases) to prevent abuse and undesired strategic use of the update mechanism. The next Section explores some of these issues.

\section{Benefits}

A decentralized patent model fosters the generation of a shared, participatory patent record, and the turning of this record into a central tool in the innovation economy. This strategy is expected to yield multiple benefits. First, it would improve the patent examination process by enhancing the knowledge and the expertise that are involved in the examination process. Second, it would turn the record into a live database of inventions that is constantly updated and referred to. Concentration of information about inventions in one place would also boost innovation by escalating information on new inventions and by driving the adoption of new inventions in the market. Finally, information benefits would also help tackle the patent troll problem - one of the most troubling issues in patent law. ${ }^{165}$

Let us begin with the examination process. This process would become significantly more efficient and precise as the patent community would shoulder the tasks of information collection with examiners and weigh in on the invention's obviousness. ${ }^{166}$ As discussed, under the current regime, the patent prosecution process is done ex parte, and generally excludes competitors of the patentee and other members of the public. ${ }^{167}$ The PTO itself is entrusted with raising potential claims in order to narrow down the patentee's claims. ${ }^{168}$ This is a task that the PTO is likely to perform in a suboptimal manner. ${ }^{169}$ This task is also time consuming and is done under constraints of time and knowledge. ${ }^{170}$

what-is-the-difference-blockchain-and-database [https://perma.cc/HUB5-35QU] (last visited Oct. 24, 2019). There are various ways to moderate content on online systems, including user moderation, commercial content moderation (CCM), user-moderated systems, and others. See Blaise Grimes-Viort, 6 Types of Content Moderation You Need to Know About, SociaL MEDIA TODAY (Dec. 7, 2010), https://www.socialmediatoday.com/content/6-types-contentmoderation-you-need-know-about [https://perma.cc/MXU6-D3TZ] (discussing the various ways to moderate online content). I believe that moderation by the PTO is critical in order to maintain the accurateness of the system and to maintain the incentives of system participants to behave responsibly. In the future it may be possible to delegate some moderation to the system itself.

165 See supra note 48 and accompanying text.

166 See supra Section II.B.1.

167 See Xue, supra note 29, at 318 ("Patent examination is an ex parte negotiation between an examiner and the patent applicant.”). But see 35 U.S.C. § 122(e) (2012 \& Supp. V 2017) (sets forth the Third-Party Preissuance Submissions).

168 Timothy B. Lee, Why the Roots of Patent Trolling May Be in the Patent Office, ARS TECHNICA (Mar. 5, 2018), https://arstechnica.com/tech-policy/2018/03/why-the-roots-ofpatent-trolling-may-be-in-the-patent-office/ [https://perma.cc/2NPS-HDPB] ("Patent examiners don't just decide whether or not to approve a patent. They're also supposed to narrow a patent's claims to make sure it only covers what the inventor actually invented.").

169 See infra Section III.C.

170 See supra Parts I.A-B. 
Decentralization would allow scientists and market players to easily share invalidating information to facilitate the work of examiners (whether PTO or practitioner-examiners). A better examination process would also reduce the need for post-examination procedures and appeals and further reduce the production problems discussed in Section I.A.

Including the cumulative knowledge and expertise of the patent community in the examination process is also expected to dramatically reduce the error rate in patentability decisions. In particular, input from third parties regarding prior art and obviousness would provide a basis to invalidate patent applications or to strike down overbroad claims and would thus help weed out unmerited patents. ${ }^{171}$ Clearly, submissions by third parties would be selective. There may be patents that would not be attacked because industry participants would not be troubled by the monopoly sphere that they create. This would mean that these patents are probably in isolated patent areas that are not active anyway. The harms to competition that may be created if such patents are erroneously granted would thus be much lower. ${ }^{172}$

Decentralization could also simplify the examination process and render it more precise. The bolder option, where scientists comprise the first line of examiners, would replace the awkward patentability decision-making — where examiners need to fill the shoes of PHOSITA and make a retroactive decision from a point of view that is not their own-with direct decision-making by PHOSITA. Even in the less radical option, where the PTO remains the only examining body, the input of PHOSITA can add important value that examiners could use. Better patentability outcomes would lead to a justified scope of monopoly: granting monopoly to inventions that feature a material improvement over the current state of technology and denying it to obvious inventions that do not. ${ }^{173}$

Consider now the post-examination virtues of a dynamic patent record. First, a constantly updated record would spread knowledge about inventions to the scientific community early in their inceptions. This benefit may be counterintuitive for some readers, who may be troubled by the risks that industry players would "steal" ideas from each other during the examination process or make other strategic use of them. This concern is valid to a certain degree and is addressed in the next Part. Yet overall, the exposure of scientists to new ideas early in their conception would generate powerful informational advantages. Much was written about the benefits of information spillovers, particularly in

171 See, e.g., Katznelson, supra note 19, at 13 (noting "that since 1990 the average number of claims in applications had been growing by $4.5 \%$ per year."); see also supra Section I.B.

172 There may be cases where after the fact industry players would be blocked by patents that they did not deem important at the time. But in these cases, where only one inventor could realize the virtue of inventions, the monopoly is probably justified. If there is invalidating evidence regarding the patent, it would always be possible to turn to post-grant procedures at the PTO or courts, as it is today.

173 See SHAVELL, supra note 2, at 152. 
the world of innovation. ${ }^{174}$ More ideas can be created more rapidly, cooperation can be formed, and the disclosed information can be a catalyst for research and development. Knowledge of patents can also prevent duplicated efforts of inventors who may otherwise continue to race unknowingly for inventions that have already been patented, generating waste and exposing themselves to infringement lawsuits.

Relatedly, enhanced information would help tackle patent strike suits. Patent trolls exploit information problems in the current regime to identify inventors who innocently penetrated the domain of one of the patents on their portfolios. ${ }^{175}$ Tackling information problems would reduce this strategic behavior and enable the innovative community to more easily avoid infringements - by either licensing patents or bypassing the need to use them. The availability of an easy platform to license patents would also encourage NPEs to offer licenses to their patents ex-ante, and if they refuse to do so, nullify the justification of posthoc demand for payment. ${ }^{176}$

Finally, decentralization of the record would introduce a platform to commercialize inventions globally. Such a platform could become a trading platform between inventors and licensees from all over the world. ${ }^{177}$ Indeed, being an inventor requires different skills than the business skills of commercializing and selling the inventions. Patentees rarely possess both skills (or are organized in firms that do), and it is hardly surprising that the vast majority of patents are never commercialized. ${ }^{178}$ In fact, inventors may not even know who they need to team up with in order to commercialize their inventions. Once the record contains licensing information, use cases, and smart contracts, cooperation with commercial bodies to bring the invention to the market is much more likely. The benefit of this policy is twofold. First and foremost, the dynamic record can further the goal of the patent system - to accelerate the path of innovation to the market. ${ }^{179}$ Second, improved commercialization would have a dynamic effect. It could spur innovation and patenting because patents would become an effective reward for inventors and a way to recoup their R\&D investment. ${ }^{180}$

\footnotetext{
174 See, e.g., Brett M. Frischmann \& Mark A. Lemley, Essay, Spillovers, 107 ColuM. L. REV. 257, 268-71 (2007).

175 See supra note 48 and accompanying text.

176 The same process can be seen in creative industries who moved from litigation strategies to transactions, often micro-transactions, over the past two decades. See, e.g., James Yang, Note, Trademark Law in the Virtual Realism Landscape, 8 N.Y.U. J. InTELL. Prop. \& ENT. L. 409, 432 (2019) (explaining that microtransactions are now more commonly seen as business strategies for video games).

177 Such platforms exist on the private market on a smaller scope as private initiatives. See, e.g., Who We Are, BERNSTEIN, https://www.bernstein.com [https://perma.cc/NXH7-KD8F] (last visited Oct. 8, 2019).

178 See supra note 75 and accompanying text.

179 See Golden, supra note 6, at 520-21 (discussing how patents stimulate disclosure and innovation).

180 See supra note 13 and accompanying text.
} 


\section{PRActical ASPects AND CONCERNS}

This Part tackles practical aspects and concerns that pertain to this proposal. I consider three issues. The first one is whether concerns over secrecy of outstanding inventions may form an obstacle for the use of the system. Second, I consider whether there are adequate incentives for market players to participate in, and contribute to, the system, in particular if they are requested to serve as examiners. Third, I explore how to avoid undesired strategic behavior by patentees and third parties when using the patent record.

\section{A. Confidentiality}

A central concern that may be raised against this proposal revolves around confidentiality of pending patent applications. The rights-for-disclosure bargain that underlies the patent system only holds, the argument goes, when in exchange for public disclosure of her invention and means of its creation, the inventor is granted a patent. ${ }^{181}$ Under the proposed model, however, the invention is exposed to the eyes (and input) of all, regardless of whether a patent is eventually granted. Beyond this theoretical angle, the risk of premature disclosure of inventions may impose competitive harms on patentees and generate a chilling effect on filing patents under the new regime. ${ }^{182}$

A deeper look, however, reveals that concerns over secrecy are overstated at best. Secrecy of outstanding inventions under the current regime is limited de jure, and even more so de facto. Patent law grants secrecy only for the first eighteen months after patent filing. ${ }^{183}$ After eighteen months, the application is disclosed to the public regardless of whether a patentability decision has been made or not - and in most cases, it has not. ${ }^{184}$ In fact, over half of patent applications are actually published earlier - within one year from filing-because the eighteen-month period counts from the earliest priority date (including, for example, foreign applications and offers to sale in the twelve months prior to the patent filing). ${ }^{185}$

Under the proposed regime, the eighteen-month confidentiality period may indeed be somewhat reduced, because under the new model, the grace period must also delay the beginning of the examination process, or at least the open phase of the examination process. ${ }^{186}$ One option is to maintain an eighteen-

181 See supra note 65 and accompanying text.

182 See Eisenberg, supra note 50, at 902 ("Patent applicants from industry might legitimately worry about competitive harm from premature disclosure of their inventions to other practitioners.").

183 See 35 U.S.C. $\S 122$ (2012 \& Supp. V 2017).

184 See id.; 37 C.F.R. $\S 1.211$ (2018).

185 See John F. Martin, The Myth of the 18-Month Delay in Publishing Patent Applications, IPWATCHDOG (Aug. 3, 2015), https://www.ipwatchdog.com/2015/08/03/the-myth-of-the-18month-delay-in-publishing-patent-applications/id=60185/ [https://perma.cc/PCW4-RPF

E] (showing the distribution of patent applications' publication date).

186 But see id. (discussing how most patents are published earlier than 18 months from filing under today's regime as well). 
month grace period and allow inventors to relinquish the grace period any time before that. ${ }^{187}$ Another option is to reduce the grace period to, say, six months, with or without the ability to relinquish the privilege. In any case, this is a quantitative difference and not a qualitative one. What is more, a short confidentiality period is not an obligatory feature of the system, and the confidentiality period can be extended to its current length if a shorter period proves to have undesirable consequences. In short, secrecy does not have to be worse under the proposed system compared to the existing one. Under both systems, competitors can have access to inventions that do not receive patent protection, basically exposing inventors to the same risks.

\section{B. Incentives to Participate}

Let us now contemplate whether there are adequate incentives to expect active participation of the patent community in the system. After all, a functioning patent record is a public good. In the absence of private incentives to participate in it, the record would be unable to achieve its goals. It is worth noting at the outset that some contributions to the patent record would be automatic or mandatory and would be independent of the goodwill of participants. For example, patent applications would be fully published, together with automatic references to similar materials on the record; litigatory information would be added by courts as created; and patentees would be under obligation to maintain the accuracy of the information on available licenses. ${ }^{188}$ This information would already feature a substantial improvement over the current regime.

It is relatively easy to see the incentives of patentees to add licensing information to the record. Adding such information would enable patentees to communicate their technology to the industry and to commercialize their inventions without much effort. Clearly, some patentees, such as big pharmaceutical companies, may prefer to continue licensing their patents individually, because this practice would enable them to enter differential contracts and to keep licensing terms confidential. ${ }^{189}$ Yet, this functionality can be extremely valuable for small companies or individual patentees that do not have the resources to negotiate each license individually, as well as for owners of vast patent portfolios who can build a cost-effective licensing model. ${ }^{190}$

How about the interests of third parties to contribute information to the record? In particular, during the examination process, technology companies and other practitioners would have an incentive to question the validity of their competitors' patents, or other patents that would curb their free operations. From their point of view, this mechanism would be a cheaper, easier way to

\footnotetext{
187 An option for early publication request exists today as well. See 37 C.F.R. $§ 1.219$ (2018).

188 See supra Section II.B.

189 See, e.g., Helsinn Healthcare v. Teva Pharm. USA, Inc., 855 F.3d 1356, 1364, 1367-68

(Fed. Cir. 2017).

190 See supra notes $176-77$ and accompanying text.
} 
battle a patent than post-review examination, let alone litigation. ${ }^{191}$ The concern may actually be that such parties would be too eager to provide invalidating information, in a way that would jeopardize the efficiency of the system. I address this concern in the next Section.

Other contributors, such as academics or scientists, may be motivated to participate by other considerations, such as reputation or exposure to new information in their field. Volunteer reviewers are the regular case in many academic frameworks, such as reviews of submissions to scientific journals and grants, and it would thus not be surprising to see scientists weigh in to voluntarily provide their input regarding an invention in their field. ${ }^{192}$ At the postexamination stage, technology firms and scientists could be referring to the record in order to avoid infringements as well as to learn of new inventions and to form collaborations. It would be more cost-effective to perform such a search on the patent record than using the tools available today. ${ }^{193}$

Would a voluntary scheme suffice for the more radical decentralization option of practitioner-examiners? Here, nonmonetary incentives would probably be unrealistic or at least suboptimal. First, it may prove challenging to recruit examiners on a voluntary basis, and this problem may prove acute in some industries, such as in the pharmaceuticals space. ${ }^{194}$ On a voluntary basis, examiners may also end up seeing too few patent cases to develop any expertise in examination. ${ }^{195}$ What is more, a voluntary setting may attract less distinguished practitioners who try to boost their reputation. ${ }^{196}$ Another problem with volunteer-examiners is a heightened concern of a self-serving agenda, such as defeating the patents of competitors. ${ }^{197}$

One option, which I eventually reject, is to compensate practitionerexaminers via royalties from inventions that they examine. This option may sound appealing at first because it would create an incentive for examiners to

191 For discussion and comparison between the PTO and court post-review and appeal procedures see supra note 4.

192 See Daryl E. Chubin \& Edward J. Hackett, Peerless Science: Peer Review and U.S. SCIENCE POLICY 91-95 (1990).

193 Large companies typically run M\&A departments to actively look for companies with complementary technology, often to identify acquisition opportunities. Market analysis providers are also providing such services. See, e.g., Find Investments, CRUNCHBASE, https://ww w.crunchbase.com [https://perma.cc/K3KP-NHWF] (last visited Oct. 8, 2019); About Our Company, Dun \& BRADSTREET, https://www.dnb.com/about-us/company.html [https://per ma.cc/7TU7-A2RS] (last visited Oct. 8, 2019).

194 On the difference between industries in the patent space see, e.g., DAN L. BURK \& MARK A. Lemley, The Patent Crisis and How the Courts Can Solve It 22-29 (2009) (criticizing the patent system's misfit to distinct technologies and industries).

195 See Chubin \& HACKETT, supra note 192.

196 It may be possible to overcome this hurdle by setting a professional threshold, though this would be difficult to do and would reduce the pool of potential examiners.

197 See Eisenberg, supra note 50, at 905 (noting, in the context of the proposal to receive the advice of practitioners in the patent application process, that " $[\mathrm{t}] \mathrm{he}$ risk of relying upon volunteers would be that the ranks of those willing to serve would tend to be dominated by those with ulterior motives of defeating the patents of competitors."). 
dig into inventions more deeply. If this could have worked, it could have also enabled curbing the upfront patent fees applicants pay. But compensation via royalties is most likely unviable. First, although commerciality is an indication for industrial application, commerciality and nonobviousness do not necessarily come together. A patent may be obvious and lack any commercial value or the other way around. ${ }^{198}$ Thus, compensating examiners through royalties may skew examiners' judgment towards patents that have a higher commercial potential or simply be unfair. Second, under such a payment system, examiners would get no compensation for patent applications that they deny, creating an incentive to grant more patents for the probability, however low, that royalties will be forthcoming.

Therefore, for the practitioner-examiners option to work, it would probably be essential to pay examiners per examination or per hour. This mechanism would tie compensation to performance goals, namely, to calibrate a set of rewards and penalties to direct the incentives of examiners. I envision such a scheme to resemble a ranking system: examiners' pay would be determined by their rank in the system. The rank would be set according to a number of factors. For example, a post-review procedure that upholds an examiner's decision would add one point to the examiner's rank. A court decision that upholds the examiner's decision will add two points to his or her ranking. Similarly, postreview processes at the PTO that invalidate examiners' decisions would induce a penalty of one point, and invalidation of decisions by courts would lead to a reduction of two points in the ranking. Another factor that should influence examiners' ranks is the promptness of their decision-making. Each patent would have an expected timeframe for examination based on data. Meeting the expected time frame would reward examiners, while missing the mark would result in a penalty. In any case, promptness should have a lower effect than quality, to avoid generating an incentive to prioritize productivity over quality.

Can such a payment option apply for PTO examiners in the more moderate form of decentralization? In theory, such a system could inject competition into the system and encourage good performance. Yet this may be challenging in reality, not only for political reasons, ${ }^{199}$ but also because of the high employee turnover at the PTO, which means that examiners may not be at the office by the time their decisions are challenged. ${ }^{200}$ Such a system is also more crucial

198 Robert P. Merges, Uncertainty and the Standard of Patentability, 7 HIGH TECH. L.J. 1, 2 (1992) (stating that the nonobvious requirement "seeks to reward inventions that, viewed prospectively, have a low probability of success"); Michael J. Meurer \& Katherine J. Strandburg, Patent Carrots and Sticks: A Model of Nonobviousness, 12 LEWIS \& CLARK L. REv. $547,557,561-62,566$ (2008) (linking obviousness to the difficulty of the project and to its likelihood of success).

199 See supra note 127 and accompanying text.

200 See Lemley \& Sampat, supra note 95, at 824 ("[T] attrition ....."); see also Data: Patent Examiners on Staff, U.S. PAt. \& Trademark OfF., https://www.uspto.gov/dashboards/patents/kpis/kpiExaminers.kpixml [https://perma.cc/K9Y E-79QY] (last visited Oct. 8, 2019). 
with a decentralized examination force because centralized entities are better equipped to otherwise enshrine doctrines with their employees. ${ }^{201}$

This blueprint for a ranking system is obviously not intended as an exhaustive list of options. More empirical and comparative research and experimentation would be required in order to achieve a formula that works well. Further, the system would have to be reevaluated and readjusted periodically to address new unforeseen challenges that the system would generate.

Clearly, a payment scheme alone, as well-calibrated as it may be, is not a guarantee against strategic use of the record by practitioner-examiners. Examiners (or their employers) might find it more lucrative to abuse the system and pay the penalty in ranking than to follow the rules. Reputation and collegiality concerns may somewhat ameliorate these concerns but cannot be relied on to cure the problem. I address these concerns in the next Section.

\section{Strategic Use of the Patent Record}

Rational actors who are invited to share input to a public patent record would probably do so in a way that would serve their own self-interests rather than serving the public good. In many cases, their interests would be aligned with the public good (such as when competitors share prior art that is unknown to examiners). In others, it may be detached and even contrary to the public interest (such as when a biased scientist offers a false assessment of an invention's obviousness). Below I discuss potential undesired strategic uses of the record and ways that the system can mitigate them. I also show that the existing system is not bias-free and argue that the proposed system would be better equipped to deal with abuse.

It is worth noting at the outset that most strategic uses of the record are not particularly troubling. Patentees may, for example, raise the price of a license artificially only to obtain an advantage with a potential acquirer. Alternatively, scientists can make obvious contributions to the record in order to boost their reputation in a certain field. Such uses are just "noise" in the system, and the market is likely to correct them without much effort.

Other strategic use, however, may require attention. Beginning with what is perhaps the most obvious concern of this model: the concern that contributors would share false information or opinions during the examination process, with the hope of skewing the outcome of the process. Biases in this regard can occur to further either applicants' interests (to receive unmerited or overbroad patents) or third parties' interests (to block merited patent applications of others). This concern may become overwhelming if big firms harness their quantitative advantage to enroll their employees in contributing to the record, when in fact, these employees would serve the interest of their employers. The risk of biased participation is clearly heightened in the practitioner-examiners option

201 See supra Section II.A.1. 
because the bias would then control the entire process and not only some of the materials in front of the examiner. ${ }^{202}$

Industry-based scientists (or their employers) may abuse the system in yet another way: they may copy or otherwise exploit the knowledge about competitors' inventions during the examination process. This concern carries a distributive angle because big firms would be able to invest more resources in crawling through the record, finding inventions that they can copy, and outpacing the original inventor. What is more, the mere possibility of such stealth can be strategically used to coerce a weaker party to agree to inferior negotiation terms.

There are a number of ways to tackle abuses of the system, in the form of system design, regulatory review, and legal liability. Beginning with the design of the record, if the record is built on the blockchain or on an equivalent technology, then every action is documented. ${ }^{203}$ This feature of the system could help obtain damages against copying or exploitation of a competitor's invention by creating a public time stamp that could prove the patentee was the source of the invention and that the copier (or a third party) had access to it. ${ }^{204}$ Knowledge of this functionality should deter abuse of the system by means of copying outstanding inventions. ${ }^{205}$

Regulatory review would also provide relief against abuse. Beyond the power of the PTO to fix errors on the record and conduct post review procedures, ${ }^{206}$ the agency would be granted power to "flag" content of contributors who have abused their powers, and in severe cases disqualify them from making any further contributions or even block their access to content on the record. This latter sanction would be an effective deterrent for reputational reasons and because it would block precluded scientists from participation in a key information platform on which their peers remain active and may result in information and a competitive disadvantage for the excluded party. The PTO should be able to preclude from the system entire firms or bodies of scientists, if abuse appears to be systematic by such bodies.

Courts could help police abusers in much the same way that they discipline other misconduct: through tort liability. Applicants who would be victimized by intentional abuse of the system should be able to sue both the fraudulent scientist, and the firm that initiated the abuse and benefitted from it, for damages. Applicants may also be able to raise contractual claims against the abuser that

202 On the other hand, it may be easier to win on appeal on the grounds of bias if the appealing party can show examiner's bias than if she can only prove that some of the materials in front of the examiner were biased.

203 See supra note 138.

204 Proving that a third party had actual knowledge of the published invention is required in order to win "provisional rights" under 35 U.S.C. $§ 154(\mathrm{~d})$, which provides that patentees may obtain retroactive reasonable royalty from an infringer. 35 U.S.C. $§ 154(d)$ (2012 \& Supp. V 2017).

205 Clearly, for this deterrent to work, copying of inventions at the examination stage must be cognizable. If reasonable royalties under 35 U.S.C. $\S 154(\mathrm{~d})$ prove to be insufficient as a deterrent, it is possible to consider increasing the damages available in this scenario.

206 See supra note 163 and accompanying text. 
involve infringement of nondisclosure or noncompete obligations that participants shall be obliged to follow. ${ }^{207}$ To be sure, it is critical to limit the litigation mechanism. Otherwise, the prospect of lawsuits may pose a chilling effect on participation in the system, and in the case of industry examiners, also encourage expensive insurance, or generate a bias in favor of granting patents rather than denying them, especially for large or litigious patent applicants. Thus, negligence or even gross negligence should not serve as a basis for lawsuits. In such cases, applicants and third parties would only have regulatory relief. Only intentional abuse of the system could serve as grounds for lawsuits.

The combination of system design, regulatory supervision, incentive-based compensation, and liability rules would probably not solve all possible abuses, but it could make the system less prone to biases than the existing system. Indeed, the PTO and its examiners are notoriously subject to biases, and the lack of transparency in the current regime serves as a fertile ground for them.

Consider first capture and other public-choice problems. Capture theory posits that special interest groups may be able to influence agencies and overwhelm more diffused, less easily coordinated interests. ${ }^{208}$ The PTO has been notoriously subject to capture and repeat-player bias. ${ }^{209}$ It has been shown, for example, that pharma and other companies have disproportional influence on the examination process, at the expense of both holders of smaller patent portfolios and the general public. ${ }^{210}$ Likewise, it was argued that the PTO suffers from "mission bias." 211 Indeed, the PTO itself once famously asserted that its "primary mission" is "to help customers get patents." ${ }^{12}$ Consider also that the PTO works nearly exclusively with a special bar of patent prosecutors in adju-

207 In the case of industry-examiners, examiners should be subject to ethical rules that could be modeled after examiners' ethical rules under the current regime. See generally ETHICS Law \& Programs Div., U.S. Patent \& Trademark Office, 2015 Summary of Ethics RULES, https://www.uspto.gov/sites/default/files/documents/sge_summary_of_ethics_rules

2015.pdf [https://perma.cc/K2AC-QE7C] These rules could be phrased and designed to enable contractual claims.

208 See, e.g., Golden, supra note 6, at 507 (describing lobbying efforts regarding patents); Craig Allen Nard, Legal Forms and the Common Law of Patents, 90 B.U. L. REV. 51, 56-57 (2010) ("[J]udicial primacy acts as a bulwark against the more politicized legislative process or capture-prone administrative rulemaking."). But see USPTO 2017 REPORT, supra note 18, at 218 (explaining assistance of the Pro Se Assistance Program to those who apply without an attorney).

209 See BURK \& LEMLEY, supra note 195, at 107 ("It is little wonder . . that the [US]PTO in the 1990s stated its mission as 'to help our customers get patents.' That's capture."); see also Golden, supra note 109, at 1098 ("USPTO examiners primarily interact with parties seeking to obtain patent rights. There is therefore natural cause for concern that USPTO personnel will become subject to a form of intellectual or informational capture and tend to view the world through patent applicants' lenses.").

210 See Golden, supra note 6, at 507.

211 See id. at 1099 ("Even if applicant interests do not capture the USPTO, the USPTO might suffer from mission bias.").

212 U.S. Pat. \& Trademark Off., Corporate Plan-2001: Patent Business 23 (2001), available at https://www.uspto.gov/about-us/performance-and-planning/corporate-plan-2001 [https://perma.cc/8SCX-VS69]. 
dicative contexts, which may make the agency rather attentive to their concerns. ${ }^{213}$ Institutional capture may easily translate to the individual level of PTO examiners, who may be contemplating their next career steps as patent prosecutors or as major patent holders. ${ }^{214}$

Second, and relatedly, because the PTO is largely self-funded by user fees, ${ }^{215}$ it has been suspected that it is biased towards granting patents so that it can collect issuance fees and maintenance fees. ${ }^{216}$ This hypothesis is supported empirically by studies that show that the PTO grants more patents in areas where fees are higher. ${ }^{217}$ The situation may be aggravated now after the AIA empowered the PTO to increase its fees and precluded Congress from diverting the PTO revenues to the general treasury. ${ }^{218}$

Both capture and budgetary biases are extremely hard to curb, and they are both going to be dramatically reduced under a decentralized regime. While some biases may carry over to the new regime, for example by influencing the regulatory overview, they would be much attenuated and better managed, in ways that are largely absent from the current regime.

\section{CONCLUSION}

The emergence of new technological capabilities offers an opportunity to reexamine well-entrenched legal systems and explore ways to make them work more efficiently. This Article focuses on the possibilities of new technologies, such as blockchain, to improve the patent system and to tackle some of the issues that have concerned the patent community for a long time. The Article proposes that a decentralized patent system can provide a better way forward

213 See U.S. Pat. \& Trademark Off., General Requirements Bulletin for Admission to the Examination for Registration to Practice in Patent Cases Before the United States Patent and TRAdemark OfFice 1-3 (2019) (listing eligibility requirements for taking the patent bar); see also Golden, supra note 109, at 1100-01 (speculating that patent attorneys may object to measures hardening patentability criteria, which may reduce their business, and that "might exert a strong gravitational pull on an administrative agency that works nearly exclusively with such lawyers and agents in adjudicative contexts, and many of whose personnel might contemplate a later career in patent prosecution.").

214 See Golden, supra note 109, at 1099.

215 See Omnibus Reconciliation Act of 1990, Pub. L. No. 101-508, § 10101, 104 Stat. 1388, 1388-391 (1990).

216 See Frakes \& Wasserman, supra note 37, at 615. The PTO collects three types of fees from applicants: examination fees that are paid when a patent application is filed, an issuance fee that is paid when a patent is granted, and an annual maintenance fee. See U.S. Pat. and Trademark Off., Fees and Payments, https://www.uspto.gov/learning-and-resourcesfee s-and-payment/uspto-fee-schedule.

217 See Michael Frakes \& Melissa Wasserman, Does Agency Funding Affect Decisionmaking?: An Empirical Assessment of the PTO's Granting Patterns, 66 VAND. L. REV. 67, 124 25 (2013) (detailing an empirical study that supports the hypothesis that the PTO's fee structure incentivizes the agency to over grant patents).

218 See Leahy-Smith America Invents Act, Pub. L. No. 112-29, §§ 10, 11, 22, 123, 125 Stat. 284, 316-25, 336 (2011) (codified in scattered sections of 28 U.S.C. and 35 U.S.C.). 
with regards to examination, registration, promulgation, and commercialization of patents.

Decentralization of the patent registry would mean that the PTO would not exercise control over the information that the patent record includes as it does today. Rather, other state and market actors would be able to write information into the patent record. This information would be available to the public based on disclosure definitions of the system rather than on the PTO rules, and the PTO would be responsible for monitoring it and correcting errors. Decentralization would enable functionality that has not existed before, which would transform the patent record from a static and limited informational tool into a key vehicle for information flow and commercialization of patents.

Clearly, this system is unable, and does not aim to, solve all the problems in the patent system. It is often the case that when new technologies appear, some in society are reluctant towards them while others keep their hopes up for the technology to solve the entirety of the issues the current system faces. A more rational approach is preferred. Decentralizing the patent system can probably take the system forward in terms of backlog reduction, patent quality, and commercialization of technology. Yet, some problems of the system will likely remain. Among other issues, big players would still have more resources to challenge patents of small ones, rather than the other way around, capture may still persist as the PTO would still possess regulatory power, and uncertainty regarding patent doctrines would remain intact.

This Article analyzes some of the incentives, the risks, and the liabilities that need to be addressed in order for such a move to be successful or even valid. But most of all, this Article should be viewed as a thought experiment to explore the optimal balance between central and decentralized operations in the patent system and the optimal role of the state and the public in the patent system. 
